Trace el ement compositi ons of $j$ adei te ( +omphaci te) in j adei t i tes from the I t oi gawa- Ohm di stri ct, Japan: I mol i cat i ons for $\mathrm{fl}$ ui d processes i $\mathrm{n}$ subduct i on zones

\begin{tabular}{|l|l|}
\hline 著者 & Mbr i shi ta Tonøaki, Ar ai Shoj i , I shi da Yoshi to \\
\hline 著者別表示 & 森下 智晃, 荒井 章司 \\
\hline $\begin{array}{l}\text { j our nal or } \\
\text { publ i cat i on ti t l e }\end{array}$ & I sl and Ar c \\
\hline vol une & 16 \\
\hline number & 1 \\
\hline page r ange & $40-56$ \\
\hline year & $2007-03-01$ \\
\hline URL & ht t p: //doi . or g/10. 24517/00010967 \\
\hline
\end{tabular}




\title{
Thematic Article \\ Trace element compositions of jadeite (+omphacite) in jadeitites from the Itoigawa-Ohmi district, Japan: Implications for fluid processes in subduction zones
}

\author{
TOMOAKI Morishita, ${ }^{1 *}$ ShoJI ARAi ${ }^{1}$ AND Yoshito Ishida ${ }^{2}$ \\ ${ }^{1}$ Graduate School of Natural Science and Technology, Kanazawa University, Kanazawa 920-1192, Japan (email: \\ moripta@kenroku.kanazawa-u.ac.jp) and Department of Earth Sciences, Faculty of Science, Kanazawa University, \\ Kanazawa, Japan
}

\begin{abstract}
Trace-element compositions of jadeite ( \pm omphacite) in jadeitites from the Itoigawa-Ohmi district of Japan, analyzed by a laser-ablation inductively coupled plasma mass spectrometry technique showed chemical zoning within individual grains and variations within each sample and between different samples. Primitive mantle-normalized patterns of jadeite in the samples generally showed high large-ion lithophile element contents, high light rare earth element/heavy rare earth element ratios and positive anomalies of high field strength elements. The studied jadeitites have no signatures of the protolith texture or mineralogy. Shapes and distributions of minerals coupled with chemical zoning within grains suggest that the jadeitites were formed by direct precipitation of minerals from aqueous fluids or complete metasomatic modification of the precursor rocks by fluids. In either case, the geochemical characteristics of jadeite are highly affected by fluids enriched in both large-ion lithophile elements and high field strength elements. The specific fluids responsible for the formation of jadeitites are related to serpentinization by slab-derived fluids in subduction zones. This process is followed by dissolving high field strength elements in the subducting crust as the fluids continue to circulate into the subducting crusts and serpentinized peridotites. The fluids have variations in chemical compositions corresponding to various degrees of water-rock interactions.
\end{abstract}

Key words: fluid, Itoigawa-Ohmi, jadeitite, serpentinite, subduction, trace-element.

\section{INTRODUCTION}

Jadeitite principally consists of jadeite $\left(\mathrm{NaAlSi}_{2} \mathrm{O}_{6}\right)$ and typically appears as tectonic inclusions in serpentinite-matrix mélanges at subduction/collision tectonic settings (Harlow \& Sorensen 2004). Jadeitites form over a wide range of pressure and temperature $(P-T)$ conditions from the lawsonite-eclogite-facies to blueschist-facies, i.e. a subduction zone (Harlow \& Sorensen 2004) (Fig. 1). Previous genetic models of jadeitite include metamorphism/metasomatism of precur-

${ }^{*}$ Correspondence.

Received 27 October 2005; accepted for publication 20 0ctober 2006. sor rocks and crystallization from a fluid (Coleman 1961; Harlow 1994; Okay 1997; Miyajima et al. 1999; Harlow \& Sorensen 2001, 2004; Shi et al. 2003, 2005a,b; Shigeno et al. 2005).

It is usually difficult to establish a direct connection between the jadeitite and premetamorphic/ metasomatic rocks. Shigeno et al. (2005) recently found abundant inclusions of quartz (+omphacite) in the core of jadeite in jadeitites from the Nishisonogi metamorphic rocks of Kyushu, Japan. They suggested that the jadeite cores were formed by an isochemical reaction of albite $=$ jadeite + quartz . The margin of the jadeite in their samples is, however, free of quartz. Shigeno et al. (2005) assumed that silica was removed from the system during jadeite formation in the form of aqueous species 


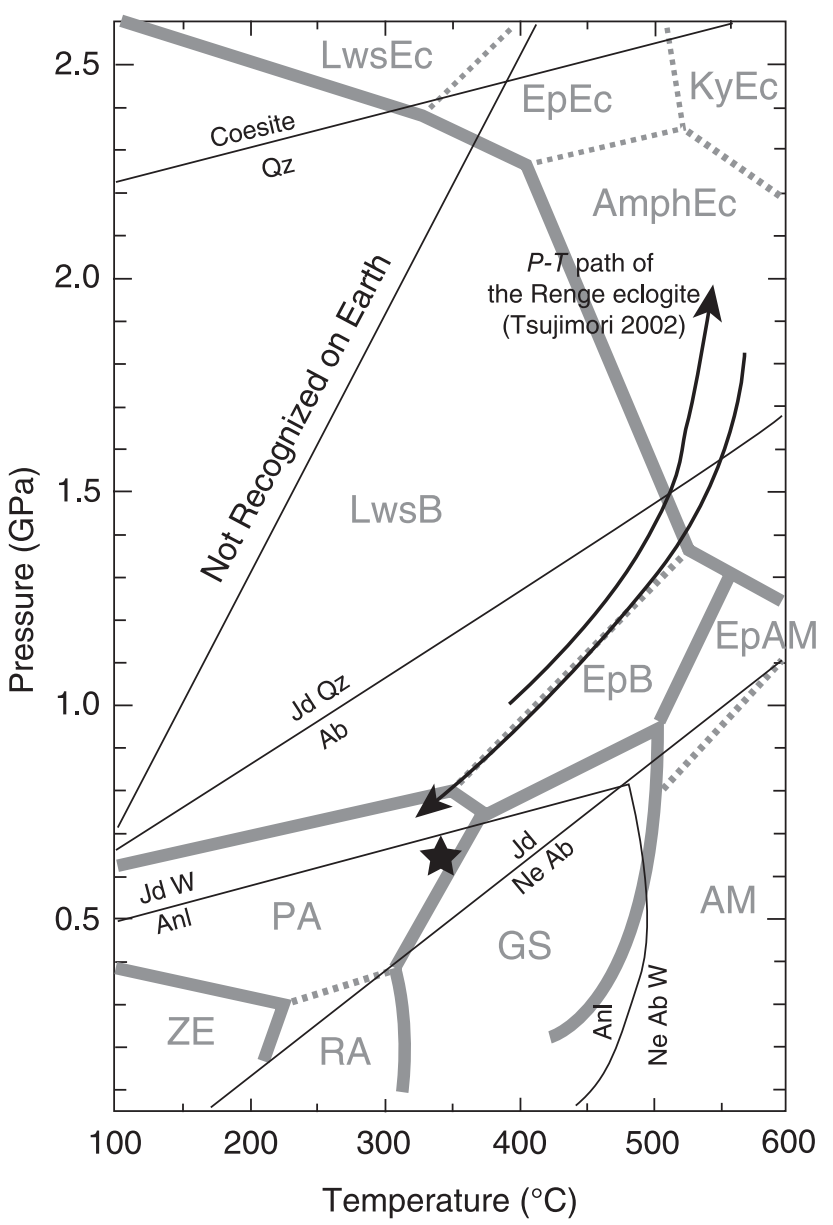

Fig. 1 Pressure and temperature $(P-T)$ diagrams for reactions related to jadeitite petrogenesis complied by Harlow and Sorensen (2004) on metamorphic facies boundaries suggested by Banno et al. (2000b). The filled star represents the $P-T$ conditions for the formation of barianfeldspar in the Lavender-Jade (Morishita 2005). The P-Tpath of the Renge eclogite (Tsujimori 2002) is also shown. AM, amphibolite facies; AmphEc, amphibole eclogite facies; EpAM, epidote amphibolite facies; EpB, epidote blueshist facies; EpEc, epidote eclogite facies; GS, greenshist facies; KyEc, kyanite eclogite facies; LwsB, lawsonite blueshist facies; LwsEc, lawsonite eclogite facies; PA, pumpellyite-actinolite facies; RA, prehniteactinolite facies; ZE, zeolite facies. Ab, albite; Anal, analcime, Jd, jadeite; $\mathrm{Ne}$, nepheline; Qtz, quartz; $\mathrm{W}, \mathrm{H}_{2} \mathrm{O}$.

in fluids. Jadeitite coexisting with quartz is a generally rare occurrence (Okay 1997; Banno et al. 2000a; Harlow et al. 2004; Shigeno et al. 2005).

In any case, jadeitites appear to reflect hydrothermal metasomatic processes in subduction zones. Aqueous fluids are released from subducting slabs by dehydration of hydrous minerals. In order to gain a better understanding of the geochemical behavior of trace elements in subduction zones, chemical evaluation of fluids, related to the formation of jadeitites, may provide unique data regarding the role of slab dehydration and/or water-rock interactions in subduction zones.

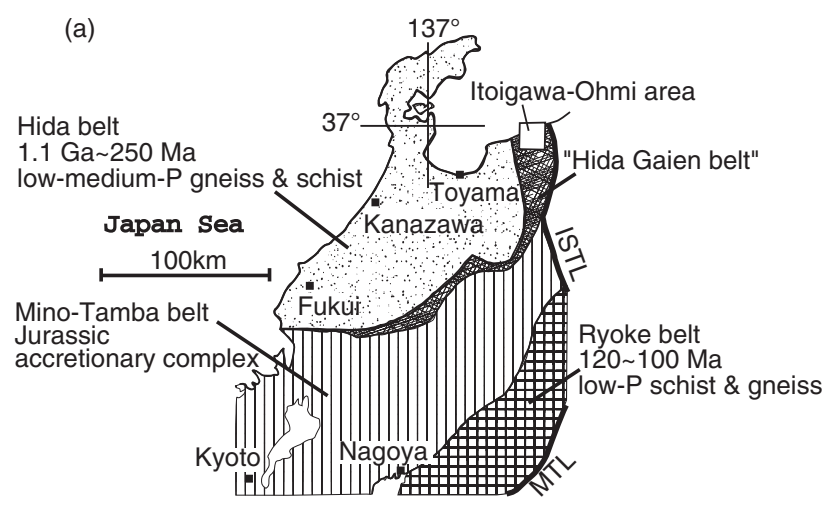

(b)

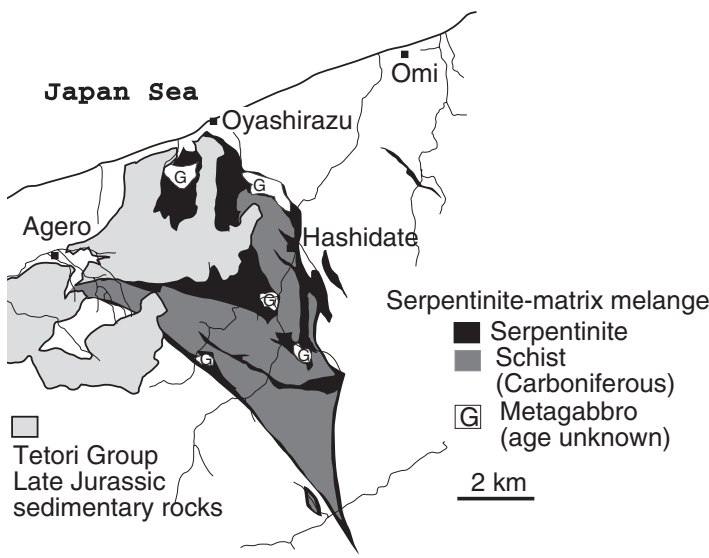

Fig. 2 (a) Simplified geotectonic and (b) geological maps of the Itoigawa-Ohmi district compiled by Tsujimori (2002). ISTL, ItoigawaShizuoka Tectonic Line; MTL, Median Tectonic Line.

The Itoigawa-Ohmi district was the first area where natural occurrences of jadeitites were reported in Japan (Kawano 1939; Ohmori 1939). The district is located in the high-P/T type Renge Metamorphic Belt, dating to the Late Paleozoic age (Shibata \& Nozawa 1968; Nishimura 1998; Tsujimori \& Itaya 1999; Kunugiza et al. 2004; Tsukada et al. 2004) (Fig. 2). Tsujimori (2002) suggested that blueschist to eclogite metamorphism may be related to the subduction of oceanic crust. Miyajima et al. (1999, 2001, 2002) and Morishita (2005) suggested that some jadeitites in the Itoigawa-Ohmi district were formed from fluids. Therefore it is probable that the fluids that are related to the formation of jadeitites in the Itoigawa-Ohmi district are affected by fluid circulation in subduction zones. This paper presents trace-element compositions of jadeite ( \pm omphacite) in jadeitites from the Iotigawa-Ohmi district. We will also discuss chemical compositions of fluids related to the formation of jadeitites in the context of fluid-assisted element circulation in subduction zones. 


\section{GEOLOGICAL OUTLINE AND GENERAL CHARACTERISTICS OF JADEITITES IN THE STUDIED AREA}

Jadeitites and eclogites in this area are thought to be tectonic inclusions in serpentinite-matrix mélanges (Banno 1958; Chihara et al. 1979; Nakamizu et al. 1989; Komatsu 1990; Nishimura 1998; Tsujimori et al. 2000; Tsujimori 2002). The ultramafic rocks in serpentinite-matrix mélanges are mainly serpentinized dunite-harzburgite and serpentine-carbonate rock (Iwao 1953; Yokoyama 1985 ) with trace amounts of chromitites (Yamane et al. 1988; Tsujimori 2004). Jadeitites in the studied area are divided into several types in terms of variations in color corresponding to mineral phases, such as white jadeitite (nearly pure jadeite), blue jadeitite (titanian omphacite and sodic amphibole), lavender jadeitite (Ti-bearing jadeite), green jadeitite (omphacite) and black jadeitite (graphite) (Iwao 1953; Chihara 1971, 1989; Oba et al. 1992; Miyajima et al. 2001).

Sr-bearing minerals (itoigawaite, rengeite and matsubaraite) sometimes occur as interstitial phases between subhedral to euhedral jadeites and/or as veins in jadeitites (Miyajima et al. 1999, 2001, 2002). The rengeite and matsubaraite are also enriched in $\mathrm{Ti}(+\mathrm{Zr})$ and are associated with titanite, zircon and rutile (Miyajima et al. 2001, 2002). Kunugiza et al. (2002) determined sensitive high mass-resolution ion microprobe (SHRIMP) zircon ages of 510-520 $\mathrm{Ma}$ in jadeitites from the Itoigawa-Ohmi district, and interpreted these ages as the formation ages of the jadeitites. These ages are much older than those of high-P/T metamorphic rocks in the studied area, which dates to $c a$ $300 \mathrm{Ma}$ (Shibata \& Nozawa 1968; Nishimura 1998; Tsujimori \& Itaya 1999; Kunugiza et al. 2004). The differences in ages between jadeitites and metamorphic rocks suggests jadeitites were not formed under the same $P-T$ conditions for the metamorphic rocks (Kunugiza et al. 2004). Sr-, Ba-, and Tibearing minerals were also found in metasomatic rocks, such as albitites and prehnite rocks, associated with serpentinite and jadeitites in the studied area (Komatsu et al. 1973; Chihara et al. 1974; Sakai \& Akai 1994; Miyajima et al. 2003).

\section{SAMPLE DESCRIPTIONS}

We examined two jadeitite samples in detail: (i) a lavender-colored jadeitite; and (ii) a light greencolored omphacite-bearing jadeitite (Lavender- (a)

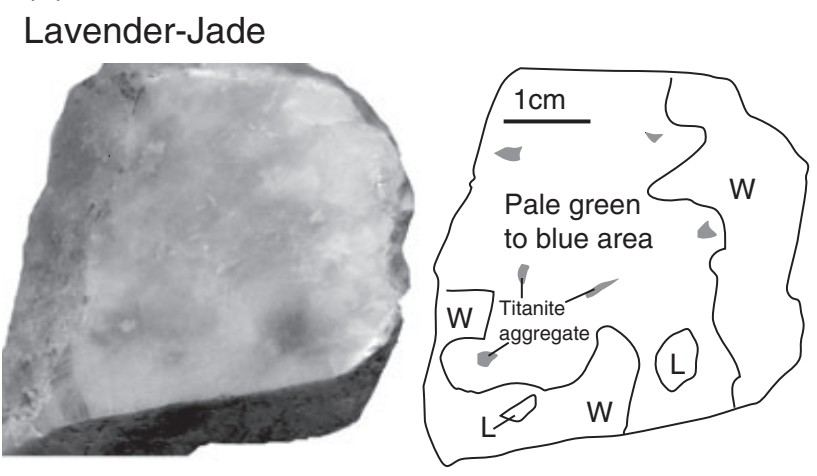

(b)

\section{Green-Omph-Jade}

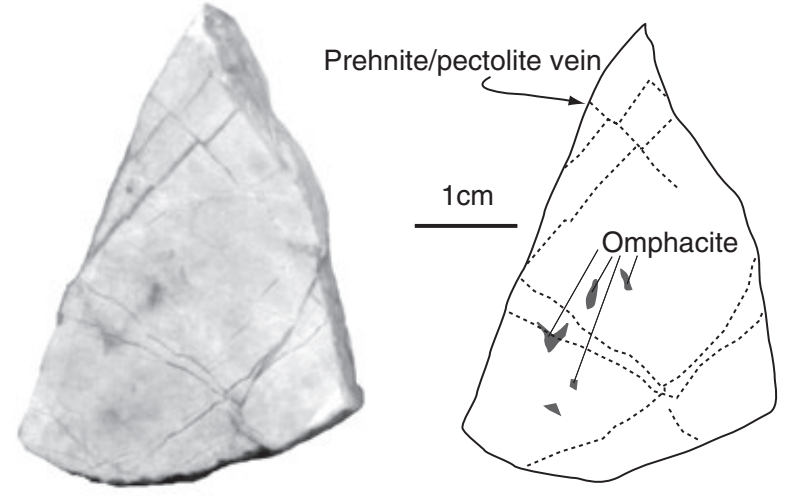

Fig. 3 Cut surfaces of the studied samples (a) Lavender-Jade (lavender-colored jadeitite), and (b) Green-Omph-Jade (light green-colored omphacite-bearing jadeitite). L, lavender-colored area; $\mathrm{W}$, white-coloured area.

Jade and Green-Omph-Jade, respectively, hereafter) (Fig. 3). Both jadeitites contained more than $90 \%$ volume of jadeite except for a part of the Lavender-Jade (see below). Albitization, replacement of jadeitite by albite, was not apparent, and quartz had not been found in either of the samples. These rock samples covered several varieties of jadetites in terms of differences in color, reflecting major element compositions and coexisting minerals. Another important point is that samples with abundant grains of more than $50 \mu \mathrm{m}$ in width, without visible inclusions/cleavages were needed for determining trace element compositions by the analytical method in this study. The cleavages were commonly well developed in the jadeite grains of our samples.

\section{LAVENDER-JADE}

The Lavender-Jade varied in color on a centimeter scale: purple, white, and pale green to blue areas reflecting the differences in mineral assemblages (Fig. 3). The purple area consisted of randomly 
Fig. 4 Occurrence of jadeite and associated minerals in the LavenderJade (lavender-colored jadeitite). Photomicrograph of purple (a) and white (b) areas. Plane polarized light. (c) Back scattered electron image of pale green to blue area where barian feldspars occurs as interstitial phase. Ba$\mathrm{f}$, barian feldspar; Jd, jadeite.

oriented prismatic jadeite (typically $<0.5 \mathrm{~mm} \times$ $<0.1 \mathrm{~mm}$ in size) in analcime matrix with a small amount of pectolite. Aggregates of the finegrained titanite associated with analcime were commonly found at the center of the purple area (Fig. 4a). The white area was an aggregate of randomly oriented prismatic jadeitite (typically $<0.3 \mathrm{~mm} \times<0.2 \mathrm{~mm}$ in size) with small amounts of pectolite, displaying a decussate texture (Fig. 4b). The pale green to blue area consisted of randomly oriented subhedral to euhedral prismatic jadeite (typically $<0.3 \mathrm{~mm} \times<0.1 \mathrm{~mm}$ in size) in a prehnite matrix with minor amounts of pectolite (Fig. 4c). The volume of jadeite was less abundant in the pale green to blue area than in the other areas. Barian feldspar was rarely distributed in the pale green to blue area. Veins of pectolite associated with a small amount of wollastonite were found.

\section{GREEN-OMPH-JADE}

The Green-Omph-Jade (Fig. 3) mainly consists of anhedral jadeite grains (typically $<0.3 \mathrm{~mm} \times$ $<0.3 \mathrm{~mm}$ and rarely up to $1 \mathrm{~mm}$, in size) (Fig. 5a,b). Omphacite mainly occurs as an aggregate of anhedral grains (Fig. 5c) and rarely as a discrete grain in a jadeite-dominant area (Fig. 3). Coexistence of omphacite and jadeite has already been reported in jadeitites from the studied area (Yokoyama \& Sameshima 1982; Oba et al. 1992). Barian feldspar is also found as a minor interstitial phase in the jadeite matrix or in the form of thin veins with pectolite $(<5 \mathrm{~mm}$ in thickness). Prehnite veins ( $<5 \mathrm{~mm}$ in thickness) cut through both the jadeitedominant area and omphacite aggregates (Figs 3,5c).

\section{MINERAL CHEMISTRY}

\section{ANALYTICAL METHODS}

Major element compositions of jadeite and omphacite were analyzed with a JEOL JXA-8800 at the Center for Cooperative Research of Kanazawa University. The analyses were performed with an accelerating voltage of $15-20 \mathrm{kV}$ and a beam current of $15-20 \mathrm{nA}$ using a $3-\mu \mathrm{m}$ diameter beam.
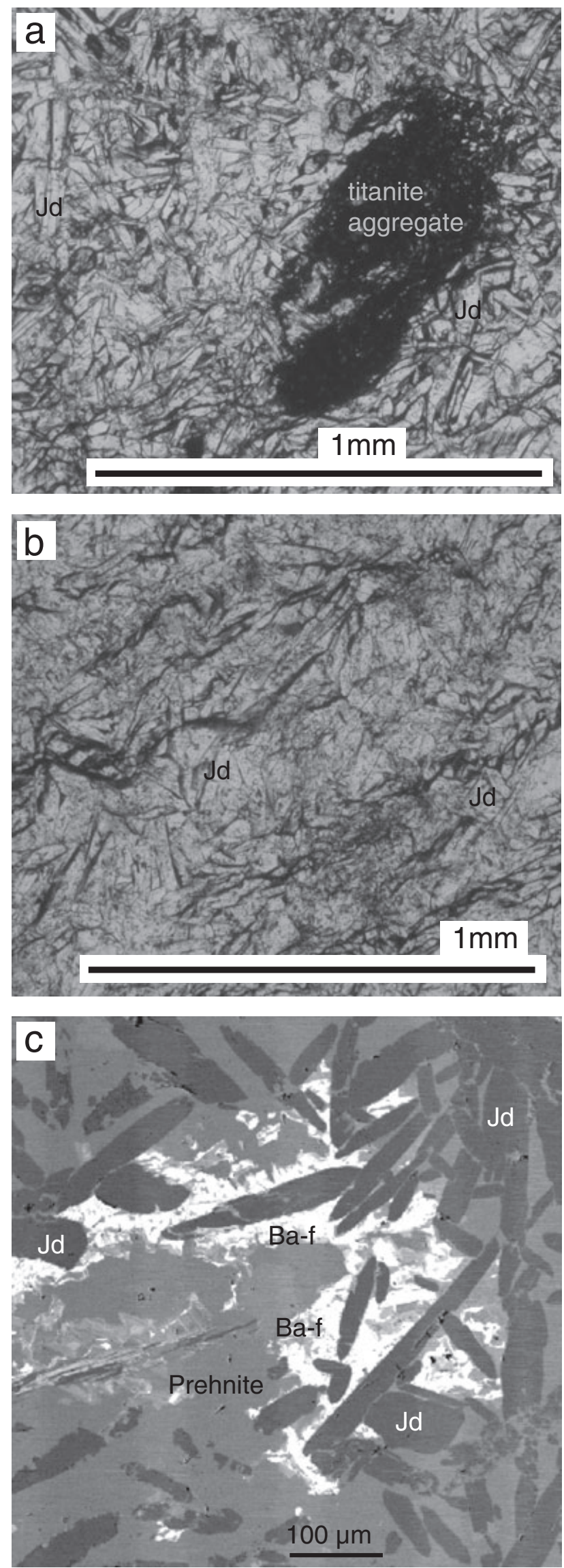

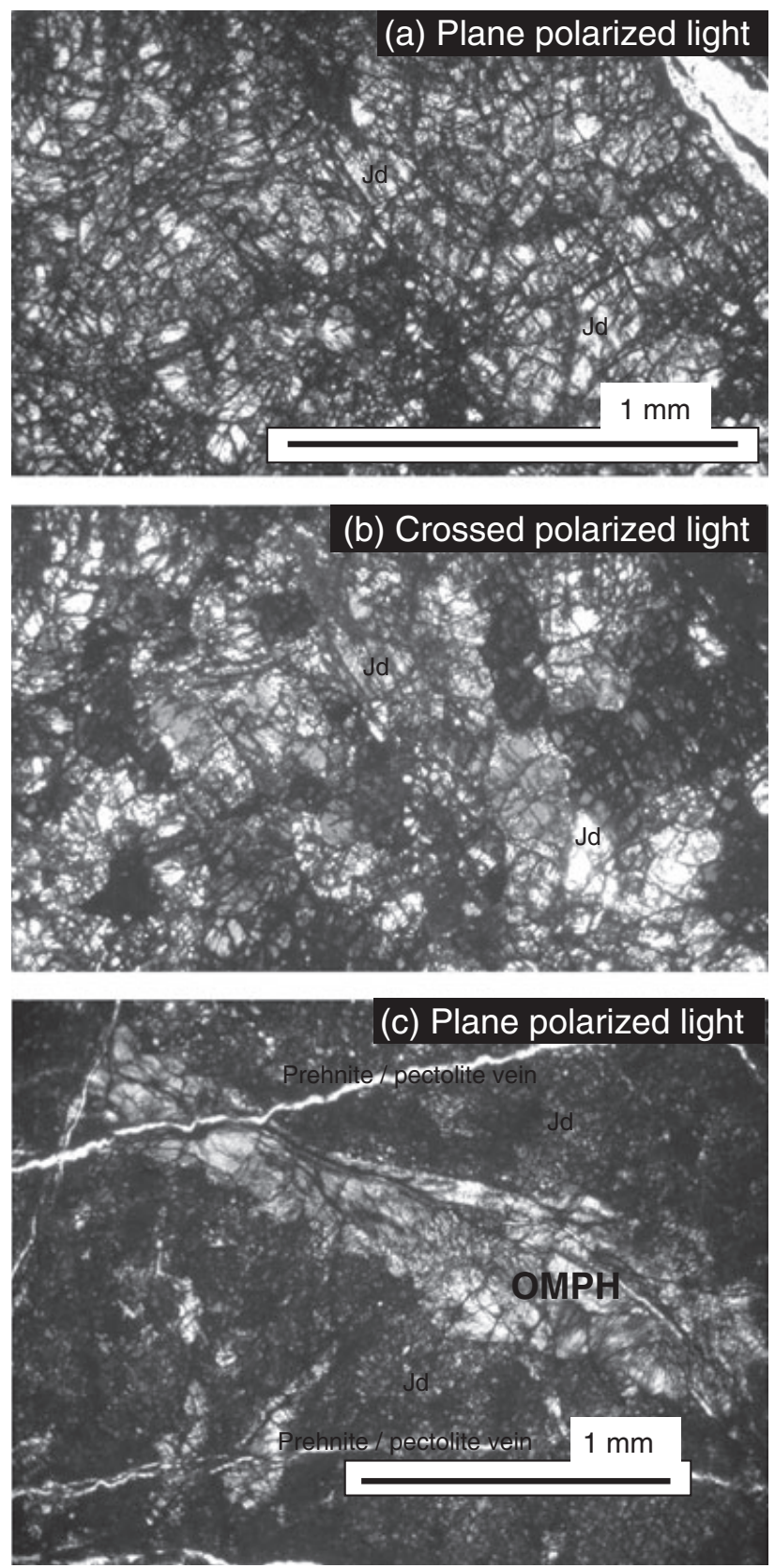

Fig. 5 Occurrence of jadeite, omphacite and associated minerals in the Green-Omph-Jade (light green-colored omphacite-bearing jadeitite). (a) Photomicrograph of jadeite-dominant area. Plane polarized light. (b) Crossed polarized light of (a). (c) Photomicrograph of omphacite aggregate $(\mathrm{OMPH})$. Plane polarized light. Jd, jadeite.

JEOL software using ZAF corrections was used. In this study, $\mathrm{Fe}^{3+}$ content of clinopyroxenes and the mole proportions of jadeite-, aegirine- and augite-end-member components were calculated after Matsumoto and Hirajima (2005) as follows. The $\mathrm{Fe}^{3+}$ was estimated using $\mathrm{Fe}^{3+}=\mathrm{Na}-\mathrm{Al}$ (where $\mathrm{Al}=\mathrm{Al}^{\text {total }}$ if $\mathrm{Si}=>2$ on the basis of $\mathrm{O}=6$, or $\mathrm{Al}=\mathrm{Al}^{\text {total }}-(2-\mathrm{Si})$ if $\left.\mathrm{Si}<2\right)$. The enstatite and ferrosilite components were ignored. $\mathrm{X}_{\mathrm{Jd}}, \mathrm{X}_{\mathrm{Aeg}}$ and
$\mathrm{X}_{\text {Aug }}$ were calculated as mole $\%$ of $\mathrm{Al}^{\mathrm{VI}} /(\mathrm{Na}+\mathrm{Ca})$, $\mathrm{Fe}^{3+} /(\mathrm{Na}+\mathrm{Ca})$ and $\mathrm{Ca} /(\mathrm{Na}+\mathrm{Ca})$, respectively.

Trace element compositions ( $\mathrm{Li}, \mathrm{Sc}, \mathrm{Ti}, \mathrm{V}, \mathrm{Cr}, \mathrm{Rb}$, $\mathrm{Sr}, \mathrm{Y}, \mathrm{Zr}, \mathrm{Nb}, \mathrm{Ba}$, selected rare earth elements (REE), Hf and $(\mathrm{Pb})$ were analyzed by laser ablation (193 nm ArF excimer: MicroLas GeoLas Q-plus)-inductively coupled plasma mass spectrometry (Agilent 7500S) (LA-ICP-MS) at the Incubation Business Laboratory Center of Kanazawa University (Ishida et al. 2004). Each analysis was carried out by ablating $30 \mu \mathrm{m}$, at $5 \mathrm{~Hz}$. The NIST SRM 612 glass was used as the primary calibration standard and was analyzed at the beginning of each batch of fewer than eight unknown analyses, with a linear drift correction applied between each calibration. The element concentration of NIST SRM 612 for the calibration was selected from the preferred values of Pearce et al. (1997). Data reduction was facilitated using ${ }^{29} \mathrm{Si}$ as an internal standard element, based on $\mathrm{SiO}_{2}$ contents obtained by EPMA analysis, and followed a protocol essentially identical to that outlined by Longerich et al. (1996). Details of the analytical method and data quality for EPMA and LAICP-MS system at Kanazawa University were described in Morishita (2005) and Morishita et al. (2005a,b), respectively.

\section{RESULTS}

CHEMICAL ZONING IN MAJOR- AND TRACE-ELEMENT COMPOSITIONS IN JADEITE

Harlow and Sorensen (2004) suggested that jadeite in jadeitites are cryptically to rhythmically zoned based on the cathodoluminescence imaging of many jadeitite samples collected from around the world, including the studied area. Sorensen et al. (2003) reported chemical zoning in trace elements in jadeite from Guatemalan jadeitites. In fact, Morishita (2005) reported a Ca-rich rind (less than a few $\mu \mathrm{m}$ in width) in a jadeite from the pale green to blue area in the Lavender-Jade. X-ray intensity maps of elements in the studied samples using EPMA revealed that jadeites, particularly the Lavender-Jade, are irregularly zoned in major and minor elements (Fig. 6). Furthermore signal intensity of some elements, particularly high field strength elements (HFSE), $\mathrm{Ba}, \mathrm{Sr}$ and light rare earth elements (LREE), in jadeite were sometimes significantly changed during laser sampling. Some of the elements demonstrated fluctuations not correlating with those of other elements (Fig. 7). No visible inclusions were observed in any 
Fig. 6 Back-scattered electron (BSE) image and $\mathrm{X}$-ray intensity maps of $\mathrm{Ca}$, Ti and $\mathrm{Zr}$ in purple area in the Lavender-Jade.
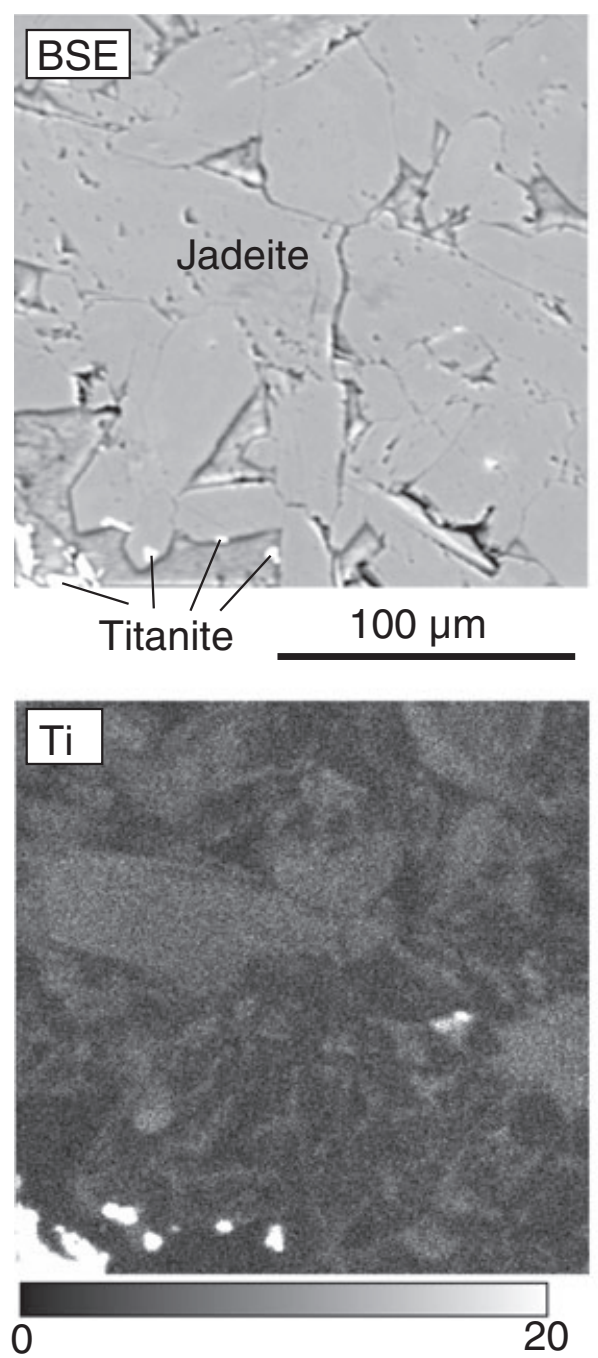
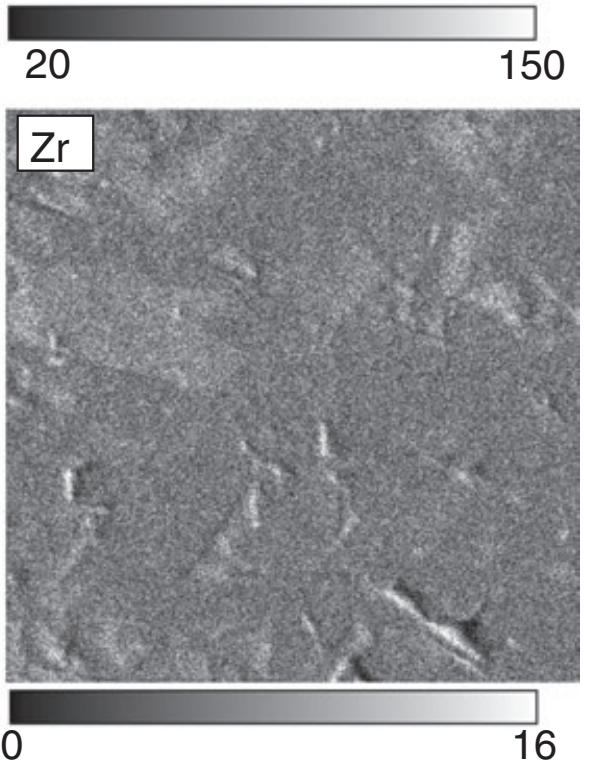

of the ablated spots. The cylindrical pits attainable with the laser-sampling suggest that it could be used to bore through grains and thereby produce vertical chemical profiles. Therefore, the variations in trace-element signal intensities observed during laser sampling were probably caused by chemical zoning within each grain rather than ablating unrecognized phases (Jackson et al. 1992). In this study, chemical zoning of trace elements in jadeite was not discussed because of limitations in spatial resolution of LA-ICP-MS analyses ( $30 \mu \mathrm{m}$ in pit diameter $\times 30 \mu \mathrm{m}$ in depth). Trace element compositions of jadeite we present here represent average compositions of each analytical volume in a jadeite grain with irregular chemical zoning. Representative analyses of major element and trace element compositions of jadeite and omphacite are shown in Table 1 and Table 2 , respectively.

\section{LAVENDER-JADE}

Jadeite in the Lavender-Jade is nearly pure jadeite $\left(\mathrm{X}_{\mathrm{Jd}}=95-99\right)$ but is slightly different in $\mathrm{CaO}$ and $\mathrm{TiO}_{2}$ contents, corresponding to the differences in colors (Morishita 2005) (Table 1). The CaO contents in jadeite from the pale green to blue area (0.1-0.8 wt\%) are slightly higher than those from other areas $(<0.1 \mathrm{wt} \%)$. The $\mathrm{TiO}_{2}$ content in jadeite is higher in the purple area $(0.3-0.7 \mathrm{wt} \%)$ than in other areas $(<0.3 \mathrm{wt} \%)$. The minute size (less than a few $\mu \mathrm{m}$ ) of the $\mathrm{Ca}$-rich rind of jadeite in the pale green to blue areas renders analysis difficult, and as such chemical compositions have never been determined (Morishita 2005).

Trace element compositions of jadeite also vary in abundance corresponding to the differences in colors, but show similar chondrite- and primitive mantle-normalized patterns among grains 
(Figs 8,9). Trace elements in jadeite tend to be more abundant in the purple area than in other areas (Figs 8,9). LREE contents in the LavenderJade are high compared to middle rare earth element (MREE) to heavy rare earth element

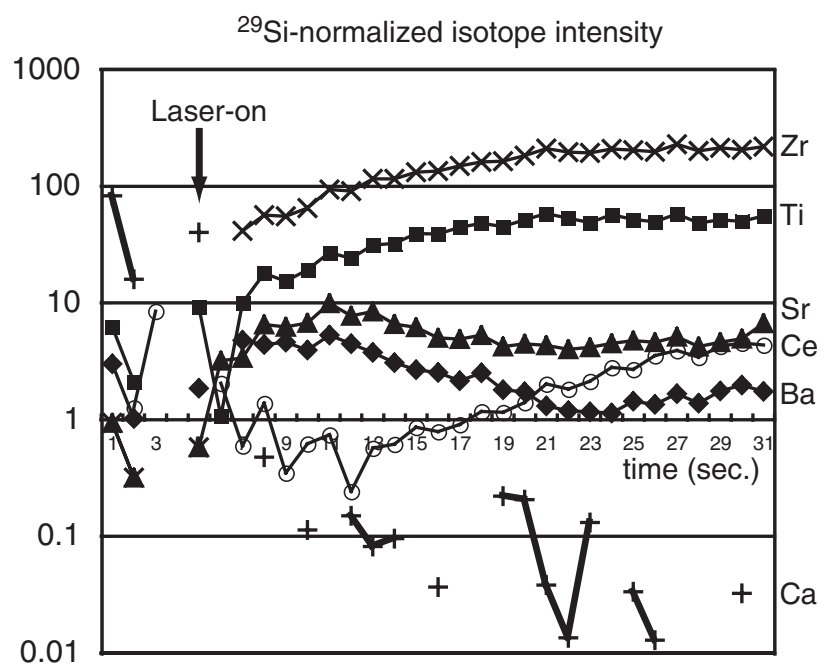

Fig. 7 Time evolution of ${ }^{29} \mathrm{Si}$-normalized intensities of ${ }^{43} \mathrm{Ca},{ }^{49} \mathrm{Ti},{ }^{88} \mathrm{Sr}$, ${ }^{90} \mathrm{Zr},{ }^{138} \mathrm{Ba}$ and ${ }^{140} \mathrm{Ce}$ before and during laser sampling into a jadeite in a lavender-colored part of the Lavender-Jade.
(HREE) $(+Y)$ which are usually lower than the detection limit of the analyses (0.02-0.1 p.p.m.: Table 1). Chondrite-normalized REE pattern of jadeite in the Lavender-Jade is characterized by high LREE/HREE ratio and has no apparent positive $\mathrm{Eu}$ anomaly (Fig. 8). The $\mathrm{Cr}$ content, which is a good indicator of contributions from surrounding peridotites in serpentinite-matrix mélanges, is lower than the detection limits (less than 5-7 p.p.m.). Abundances of $\mathrm{Sr}, \mathrm{Ba}$ and $\mathrm{Li}$, which are fluid-mobile elements, are 10110 p.p.m., 2-13 p.p.m and 5-15 p.p.m., respectively. However, $\mathrm{Pb}$ content, which is expected to be abundant in subduction-related fluids, is lower than the detection limit (less than 0.3 p.p.m.). A primitive mantle-normalized trace element pattern of jadeite is characterized by strong positive anomalies of HFSE (Fig. 9). It is interesting to note that the primitive mantle-normalized trace element patterns of jadeites from the white and pale green to blue areas also show strong positive anomalies of HFSE, although HFSE-rich minor minerals are not found near the analyzing spot. Trace-element characteristics of jadeite are similar to those in Guatemalan jadeitites high in $\mathrm{Li}$,

Table 1 Major-element compositions of jadeite and omphacite

\begin{tabular}{|c|c|c|c|c|c|c|c|c|c|c|c|c|}
\hline \multirow[t]{4}{*}{ wt $\%$} & \multicolumn{6}{|c|}{ Lavender-colored jadeitite } & \multicolumn{6}{|c|}{ Green-omphacite jadeitite } \\
\hline & \multirow{2}{*}{\multicolumn{2}{|c|}{$\begin{array}{l}\text { Jadeite } \\
\text { Purple }\end{array}$}} & \multicolumn{2}{|c|}{ White } & \multirow{2}{*}{\multicolumn{2}{|c|}{$\begin{array}{l}\text { Pale green } \\
\text { to blue }\end{array}$}} & \multirow{2}{*}{\multicolumn{2}{|c|}{ Jadeite }} & \multirow{3}{*}{$\begin{array}{l}\text { Omphacite } \\
\text { Discrete }\end{array}$} & \multirow[t]{3}{*}{ Discrete } & \multirow{2}{*}{\multicolumn{2}{|c|}{ Aggregate }} \\
\hline & & & $(n=5)$ & SD & & & & & & & & \\
\hline & $(n=11)$ & SD & & & $(n=6)$ & $\mathrm{SD}$ & $(n=11)$ & $\mathrm{SD}$ & & & $(n=11)$ & SD \\
\hline $\mathrm{SiO}_{2}$ & 59.6 & 0.39 & 59.7 & 0.24 & 59.7 & 0.26 & 59.5 & 0.39 & 56.7 & 57.3 & 57.1 & 0.24 \\
\hline $\mathrm{TiO}_{2}$ & 0.50 & 0.22 & 0.19 & 0.09 & $<0.04$ & & $<0.04$ & & $<0.04$ & $<0.04$ & 0.08 & 0.04 \\
\hline $\mathrm{Al}_{2} \mathrm{O}_{3}$ & 24.4 & 0.45 & 25.1 & 0.34 & 25.1 & 0.34 & 24.5 & 0.34 & 13.1 & 12.2 & 11.5 & 0.81 \\
\hline $\mathrm{Cr}_{2} \mathrm{O}_{3}$ & $<0.04$ & & $<0.04$ & & $<0.04$ & & $<0.04$ & & $<0.04$ & $<0.04$ & 0.06 & 0.04 \\
\hline $\mathrm{FeO}^{\dagger}$ & 0.23 & 0.14 & 0.11 & 0.17 & 0.07 & 0.02 & 0.12 & 0.13 & 1.8 & 4.2 & 1.2 & 0.14 \\
\hline $\mathrm{MnO}$ & $<0.07$ & & $<0.07$ & & $<0.07$ & & $<0.07$ & & $<0.07$ & 0.10 & $<0.07$ & \\
\hline $\mathrm{MgO}$ & 0.22 & 0.23 & 0.02 & 0.04 & 0.11 & 0.15 & 0.16 & 0.18 & 7.5 & 6.8 & 9.1 & 0.75 \\
\hline $\mathrm{CaO}$ & 0.29 & 0.27 & 0.08 & 0.03 & 0.33 & 0.18 & 0.24 & 0.27 & 11.4 & 10.5 & 12.9 & 0.91 \\
\hline $\mathrm{Na}_{2} \mathrm{O}$ & 15.1 & 0.26 & 15.3 & 0.18 & 15.1 & 0.14 & 15.1 & 0.27 & 8.6 & 9.2 & 7.5 & 0.52 \\
\hline $\mathrm{K}_{2} \mathrm{O}$ & 0.02 & 0.01 & 0.02 & 0.01 & $<0.02$ & & 0.02 & 0.01 & 0.05 & 0.05 & 0.02 & 0.01 \\
\hline $\mathrm{NiO}$ & $<0.06$ & & $<0.06$ & & $<0.06$ & & $<0.06$ & & $<0.06$ & $<0.06$ & $<0.06$ & \\
\hline total & 100.3 & 0.63 & 100.5 & 0.51 & 100.4 & 0.47 & 99.6 & 0.55 & 99.3 & 100.3 & 99.6 & 0.51 \\
\hline \multicolumn{13}{|c|}{ Numbers of cations on the basis of $\mathrm{O}=6$} \\
\hline $\mathrm{Si}$ & 2.00 & 0.003 & 2.00 & 0.005 & 2.00 & 0.003 & 2.01 & 0.002 & 2.00 & 2.02 & 2.01 & 0.005 \\
\hline $\mathrm{Ti}$ & 0.01 & 0.006 & 0.00 & 0.002 & & & & & & & 0.00 & 0.001 \\
\hline $\mathrm{Al}$ & 0.97 & 0.017 & 0.99 & 0.010 & 0.99 & 0.010 & 0.97 & 0.010 & 0.55 & 0.51 & 0.48 & 0.033 \\
\hline $\mathrm{Cr}$ & & & & & & & & & & & 0.00 & 0.001 \\
\hline $\mathrm{Fe}^{\dagger}$ & 0.01 & 0.004 & 0.00 & 0.005 & 0.00 & 0.001 & 0.00 & 0.004 & 0.05 & 0.12 & 0.03 & 0.004 \\
\hline $\mathrm{Mn}$ & & & & & & & & & & 0.00 & & \\
\hline $\mathrm{Mg}$ & 0.01 & 0.012 & 0.00 & 0.002 & 0.01 & 0.007 & 0.01 & 0.009 & 0.40 & 0.36 & 0.48 & 0.039 \\
\hline $\mathrm{Ca}$ & 0.01 & 0.010 & 0.00 & 0.001 & 0.01 & 0.007 & 0.01 & 0.010 & 0.43 & 0.40 & 0.49 & 0.034 \\
\hline $\mathrm{Na}$ & 0.99 & 0.015 & 0.99 & 0.007 & 0.98 & 0.007 & 0.99 & 0.017 & 0.59 & 0.63 & 0.51 & 0.035 \\
\hline $\mathrm{K}$ & 0.00 & 0.000 & 0.00 & 0.000 & & & 0.00 & 0.001 & 0.00 & 0.00 & 0.00 & 0.001 \\
\hline \multicolumn{13}{|l|}{$\mathrm{Ni}$} \\
\hline total & 4.00 & & 4.00 & & 3.99 & & 4.00 & & 4.02 & 4.04 & 4.01 & \\
\hline
\end{tabular}

N, numbers of analyses; SD, standard deviation, $\mathrm{FeO}^{\dagger}$ and $\mathrm{Fe}^{\dagger}=$ total $\mathrm{Fe}$. 


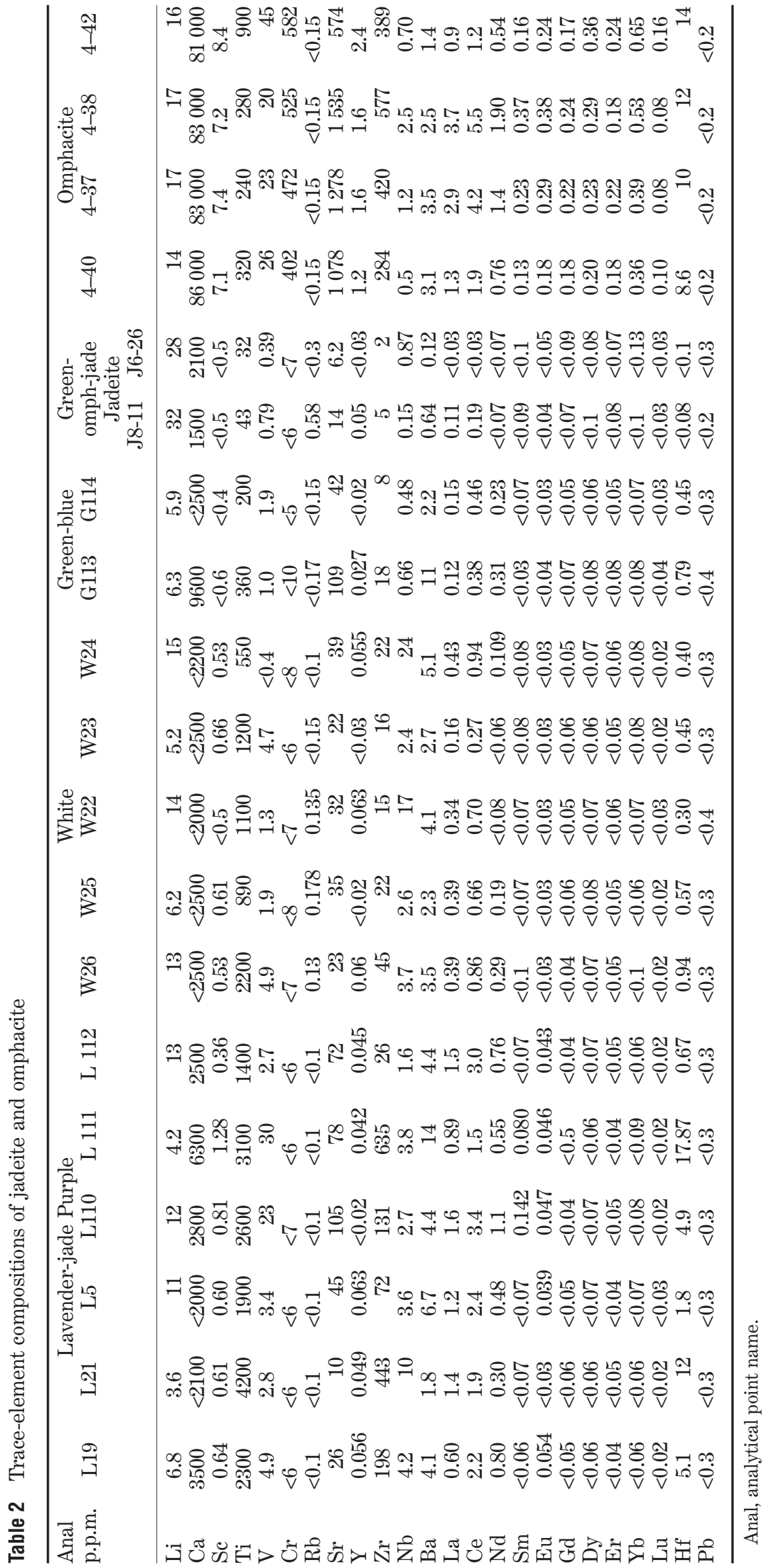



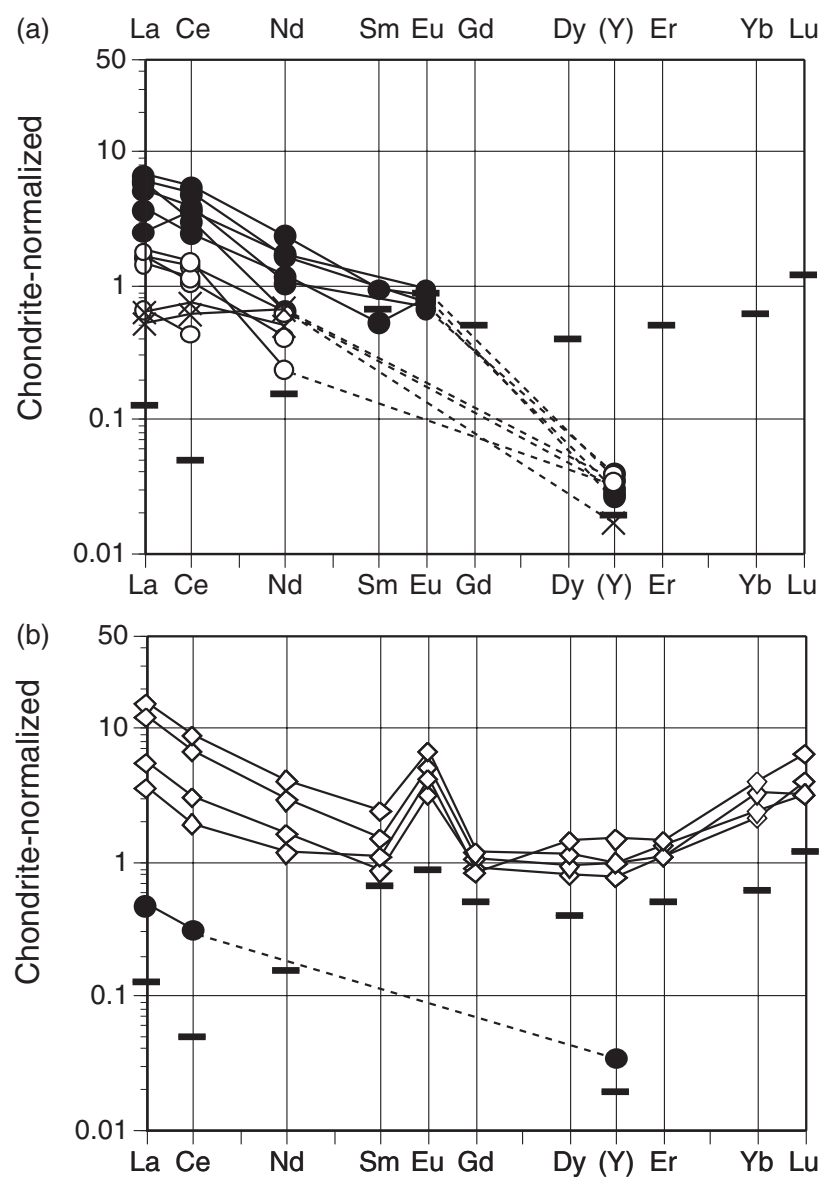

Fig. 8 Chondrite-normalized rare earth element (REE) patterns of jadeite \pm omphacite. (a) Lavender-jade. Purple $(-\mathbf{-})$; white $\left(-\mathrm{O}_{-}\right)$; green-blue $(-X-)$; typical detection limit $(-)$. (b) Green-omph-jade. Omphacite $(\diamond)$; jadeite $(\mathbf{O})$. The chondrite values are from McDonough and Sun (1995). Green-blue: pale green to blue area in the Lavender-Jade.

Rb, Be, REE, Zr and Ti (Sorensen et al. 2003). Li content of jadeite in the Lavender-Jade ranges from 4 to 14 p.p.m. (Fig. 10, Table 2).

\section{GREEN-OMPH-JADE}

Jadeite in the Green-Omph-Jade is also nearly pure jadeite $\left(\mathrm{X}_{\mathrm{Jd}}=98\right)$ (Table 1$)$. The $\mathrm{CaO}$ and $\mathrm{TiO}_{2}$ contents in jadeite are less than $1.0 \mathrm{wt} \%$ and less than $0.1 \mathrm{wt} \%$, respectively. Omphacite shows slight differences in major-element compositions between omphacite aggregates and discrete grains (Table 1). Omphacite in omphacite aggregates is relatively homogeneous in major-element compositions $\left(\mathrm{X}_{\mathrm{Jd}}=48 \pm 3, \mathrm{X}_{\text {Aeg }}=49 \pm 3\right.$ and $\left.\mathrm{X}_{\text {Aug }}=3 \pm 1\right)$ whereas omphacite in jadeite-dominant areas tends to be high in $\mathrm{Na}_{2} \mathrm{O}$ and $\mathrm{FeO}^{\text {total }}$ contents, $\mathrm{X}_{\mathrm{Jd}}$ (50-54) and $\mathrm{X}_{\text {Aeg }}(4-11)$. The $\mathrm{TiO}_{2}$ and $\mathrm{Cr}_{2} \mathrm{O}_{3}$ contents of omphacite are lower than the detection limit of the analysis $(<0.04 \mathrm{wt} \%)$.
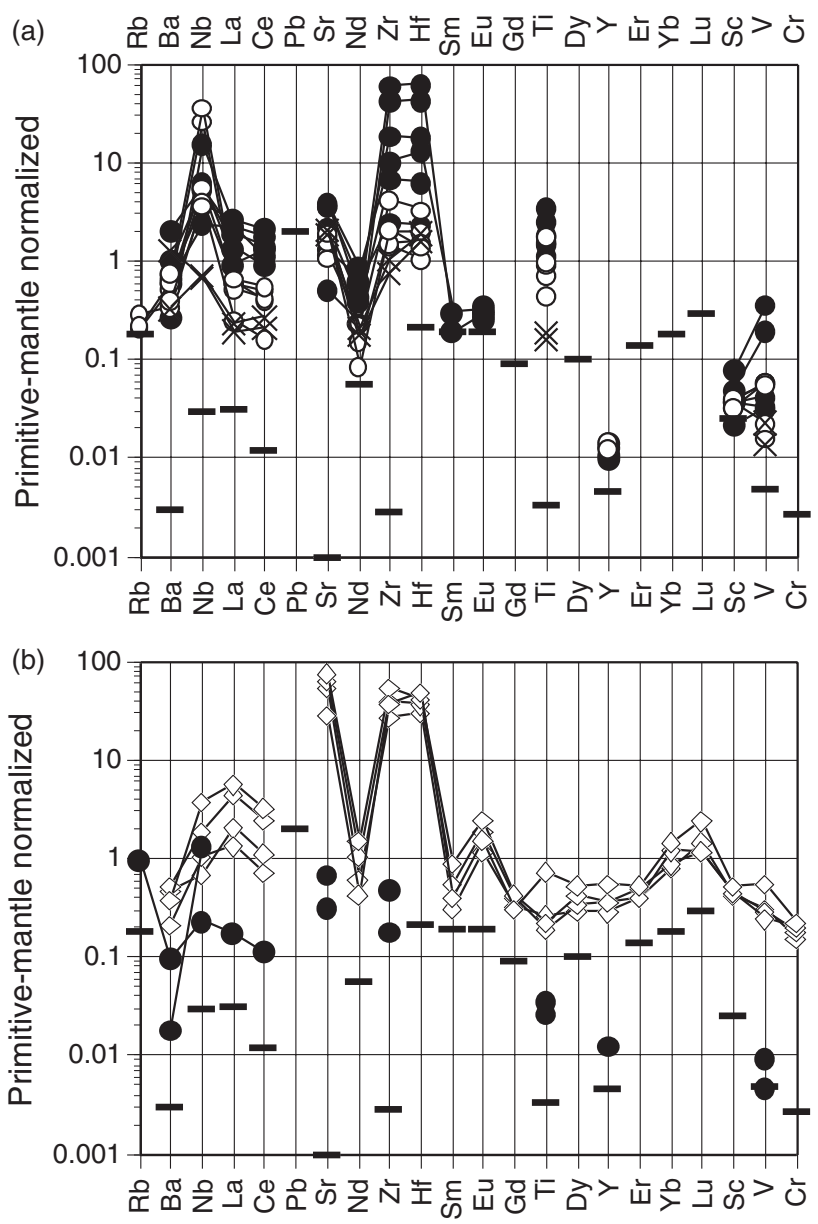

Fig. 9 Primitive-mantle normalized trace-element patterns of jadeite \pm omphacite. (a) Lavender-jade. Purple (-O-); white (-○-); green-blue $(-X-)$; typical detection limit $(-)$. (b) Green-omph-jade. Omphacite $(\diamond)$; jadeite $(\bullet)$. The primitive-mantle values are from McDonough and Sun (1995). Green-blue: pale green to blue area in the Lavender-Jade.

Abundance of trace elements in jadeite in the Green-Omph-Jade is low compared with those in the Lavender-Jade (Figs 8,9). Jadeite in the Green-Omph-Jade is usually low in REE contents, typically lower than the detection limit of the analysis $(<0.02-0.1$ p.p.m.) (Fig. 8), but still contains detectable amounts of some large-ion lithophile elements (LILE) (Ba, Sr) and HFSE (Nb, Zr) (Fig. 9). It is noted that $\mathrm{Li}$ content of jadeite is high (ca 30 p.p.m.) relative to those of omphacite (14-17 p.p.m.) and jadeite in the Lavender-Jade (Fig. 10) (Table 2). Due to its minute size, omphacite existing as discrete grains in the jadeitedominant matrix has never been analyzed. Omphacite in omphacite aggregates is only discussed in terms of its trace-element content hereafter. Omphacite is more abundant in trace-element contents than jadeite, except for Li. Chondritenormalized REE patterns of omphacite show a 


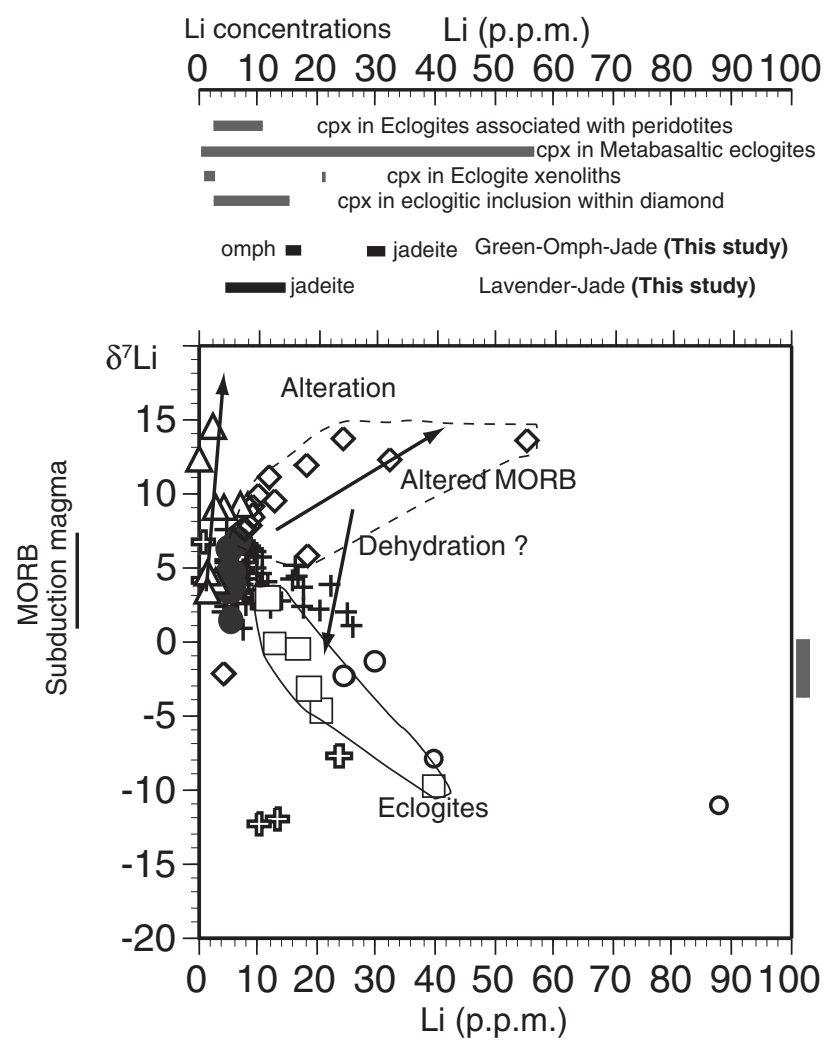

Fig. $10 \mathrm{Li}$ concentration of jadeite compared with a diagram of $\delta 7 \mathrm{Li}$ $\left(=\left[\left\{{ }^{7} \mathrm{Li} /{ }^{6} \mathrm{Li}\right\}_{\text {sample }} /{ }^{7} \mathrm{Li} /{ }^{6} \mathrm{Li}\right\}_{\text {standard }}-1\right] \times 1000$ : Chan \& Edmond 1988) Li abundance relationships. Data are as follows: Fresh mid-ocean ridge basalt (MORB) (O) (Chan et al. 1992; Moriguchi \& Nakamura 1998); altered MORB $(\diamond)$ (Chan et al. 1992); subduction zone magmas (+) (Moriguchi \& Nakamura 1998; Chan et al. 2002; Tomascak et al. 2002; Leeman et al. 2004); Japan-arc peridotite xenoliths (\$) (Nishio et al. 2004); eclogites (whole-rock, $\square$ ) (omphacite, $\bigcirc)$ (Zack et al. 2003); and serpentinized abyssal peridotites $(\triangle)$ (Decitre et al. 2002). Li concentrations of clinopyroxene in eclogites and eclogitic rocks from various tectonic setting (Woodland et al. 2002) and in diamond (Seitz et al. 2003) are also shown. The $\delta^{7}$ Li of Guatemalan jadeitites is from Simons et al. (2004).

U-shape with a Eu-positive anomaly (Fig. 8). The primitive-mantle normalized trace element pattern of omphacite has strong positive anomalies of Sr, Hf and Zr (Fig. 9).

\section{DISCUSSION}

\section{ORIGIN OF THE STUDIED JADEITITES}

A breakdown reaction of albite into jadeite and quartz (albite $=$ jadeite + quartz) is considered a reaction for the formation of jadeite in highpressure metamorphism (Fig. 1). The systematic absence of quartz coexisting with jadeite in the studied jadeitites, however, precludes formation by this reaction in a closed system. The protolith texture or mineralogy cannot be recognized in the studied jadeitites. Jadeite in the studied jadeitites is characterized in trace elements by enrichment of LILE and HFSE relative to HREE. Geochemical characteristics of jadeite are not directly consistent with those expected for feldspars. Jadeite in the studied sample is heterogeneous in chemical compositions and could possibly show cryptic trace element zoning within each grain (Fig. 5). Some jadeites have euhedral shapes and are randomly oriented in matrix phases (Fig. 4c), indicating a low degree of plastic deformation. These lines of evidence favor that the jadeitites were directly crystallized from aqueous fluids, as suggested by Harlow and Sorensen (2001, 2004). Miyajima et al. (1999, 2001, 2002) and Morishita (2005) suggested that Sr-Ba-rich minerals were formed from residual fluids after the formation of jadeite because $\mathrm{Sr}$ and $\mathrm{Ba}$ are incompatible with clinopyroxene (Green \& Adam 2003).

Recently Shigeno et al. (2005) reported the presence of quartz inclusions in the core of jadeite in some jadeitites from the Nishisonogi metamorphic rocks, Japan. However, they also reported quartz-free margins in the same jadeite grain. They suggested that the core of jadeitite was formed by the isochemical reaction, albite = jadeite + quartz, at high $P-T$ conditions. On the other hand, the quartz-free margin of the jadeite was interpreted as being formed by removal of the $\mathrm{SiO}_{2}$ component as an aqueous silica species in the intergranular fluid during the reaction. We cannot completely exclude the possibility that the studied jadeites were formed by metamorphism coupled with complete metasomatic modification of the precursor rocks by fluids. Even in this case, however, geochemical characteristics of the studied sample should be strongly affected by chemical compositions of fluids passing through it.

Estimation of $P-T$ conditions for the formation of the jadeitites is critical to the interpretations of jadeitite petrogenesis. Jadeitite lacking quartz requires only $P>0.5-0.6 \mathrm{GPa}$ to form (Harlow 1994; Harlow \& Sorensen 2004) (Fig. 1). Jadeiteanalcime relationships in the Lavender-Jade provide information on pressure and temperature. Analcime is closely associated with Ti-rich jadeite in a lavender-colored area of the Lavender-Jade, although it is not common in the other areas. A reaction, jadeite $+\mathrm{H}_{2} \mathrm{O}=$ analcime is a relatively temperature-insensitive reaction $(0.6-0.8 \mathrm{GPa}$ at $300-450^{\circ} \mathrm{C}$ ) (Fig. 1). Prehnite coexists with jadeite in a pale green to blue area of the Lavender-Jade. Prehnite is common in low-grade metamorphic rocks $\left(<350^{\circ} \mathrm{C}\right)$ (Frey et al. 1991; Spear 1993; 
Banno 1998; Miyazaki \& Okamura 2002). The $P-T$ stability of low-grade metamorphic facies has been carefully studied by several authors (Frey et al. 1991; Banno 1998; Miyazaki \& Okamura 2002). The high-pressure limit for the prehnite stability field does not exceed $0.45 \mathrm{GPa}$ for an average metabasite and some specific samples (Frey et al. 1991). However, these data were calculated based on the presence of excess chlorite + quartz + water. Quartz and chlorite are not found in the studied jadeitites, and bulk chemical compositions of the studied samples are apparently different from metabasite. Therefore, these results are not directly attributed to the studied jadeitite. The stability field of prehnite is up to $P<0.6 \mathrm{GPa}$ at $T=150-420^{\circ} \mathrm{C}$ in the $\mathrm{CaO}-\mathrm{Al}_{2} \mathrm{O}_{3}-\mathrm{SiO}_{2}-\mathrm{H}_{2} \mathrm{O}$ system (Frey et al. 1991). Jadeite-omphacite relationships in the Green-Omph-Jade are also consistent with $\mathrm{T}$ less than $400^{\circ} \mathrm{C}$ although the solvus has never been constrained well enough to interpret the chemical gap between jadeite and omphacite. Studies of fluid inclusions and oxygen isotopes in some jadeitites from different localities have generally yielded temperatures of $250-400^{\circ} \mathrm{C}$ (Johnson \& Harlow 1999; Shi et al. 2003, 2005a,b; Sorensen et al. 2003). Morishita (2005) suggested that barian feldspar in the Lavender-Jade was formed at a pressure of approximately $0.6 \mathrm{GPa}$ and a temperature of less than $350^{\circ} \mathrm{C}$ (Fig. 1). Because barian feldspars appear in the interstitial phase and sometimes cut jadeite, they apparently developed after the formation of jadeite. In conclusion, $P-T$ conditions recorded in the studied jadeitites are $P=c a 0.6 \mathrm{GPa}$ and $T$ less than or equal to $400^{\circ} \mathrm{C}$, i.e. a high- $P-T$ regime, consistent with a subduction zone setting.

\section{FLUID PROCESSES RELATED TO THE FORMATION OF THE STUDIED JADEITITES}

Geochemical characteristics of jadeite are demonstrated to be high in LILE and HFSE, and are expected to reflect fluid compositions related to the formation of the jadeitites as suggested above. Strontium and $\mathrm{Ba}$ (i.e. LILE) are generally thought to be fluid-mobile element, whereas mobility of HFSE is considered to be very low in aqueous fluids. It should be emphasized that jadeite (+omphacite) located far from titanite aggregate and the Green-Omph-Jade are also enriched in HFSE. Some minor Sr- and Ba-rich minerals in jadeitites from the studied area are enriched in HFSE (Miyajima et al. 2001, 2002). In addition, Kunugiza et al. (2002) examined the cathode lumi- nescence (CL) image and trace-element compositions of zircons in jadeitites collected from the studied area and suggested that zircons were formed from fluids, rather than from the physical introduction of zircons into jadeitites from the country rocks. We concluded that the fluids related to the formation of jadeitite had unique geochemical characteristics enriched in both LILE and HFSE.

Several field studies demonstrate that HFSErich minerals, such as rutile and zircons, were crystallized from fluids, indicating that HFSE is somewhat mobile in certain environments (Van Baalen 1993; Vard \& Williams-Jones 1993; Rubatto et al. 1998, 1999; Beard \& Hopkinson 2000; Dubińska et al. 2004; Carswell \& van Roermund 2005). The very high $\mathrm{pH}$ conditions of fluids are a plausible reason for high concentrations of HFSE in fluids (Vard \& Williams-Jones 1993; Dubińska et al. 2004). Dubińska et al. (2004) reported many zircons of hydrothermal origin in rodingite (Sudetic ophiolite), which is a Ca-rich, $\mathrm{SiO}_{2}$-undersaturated rock formed by Ca-metasomatism of silicate rocks accompanying serpentinization. High $\mathrm{pH}$ is typical of fluids derived from serpentinized ultramafic rocks (Barnes et al. 1967, 1978; Barnes \& O’Neil 1969; Kelley et al. 2001). Jadeitite typically occurs as tectonic inclusions in serpentinitematrix mélanges (Harlow \& Sorensen 2004). The estimated P-T conditions for the studied jadeitites are also consistent with those for the serpentinite hosts in the studied area (Tsujimori 2004). Johnson and Harlow (1999) examined $\mathrm{O}$ and $\mathrm{H}$ isotope compositions of jadeitites (and albitites) from the Motagua Valley, Guatemala, and suggested that metasomatic fluids related to the formation of the jadeitites were derived from serpentinization reactions in peridotites. Therefore, serpentinization is probably an important process for the production of fluid related to the formation of jadeitite in subduction environments.

A plausible explanation for the formation of the jadeitites is as follows. At the initial stage of subduction the mantle wedge peridotites just above the subducting slab will be pervasively serpentinized by LILE- $\mathrm{H}_{2} \mathrm{O}$-rich fluid, supplied by the subducting slab. Widespread metasomatism may occur along the boundary between the mantle wedge and subducting slab, where serpentinite is expected to be incorporated into the subducting plate (Maekawa et al. 2004) (Fig. 11). A specific fluid potential for the formation of jadeitite is generated at this time and place. If this fluid continues to circulate into the subducting slab, it dissolves 
elements including HFSE from the country rock (subducting crustal rocks) and transports them, at least, over short distances (Fig. 11). Highly variable trace-element abundances in jadeite within a sample, as well as among the samples, suggest that diverse fluid compositions are recorded by different jadeitite blocks in the same geological unit. Fluids involved in jadeitite crystallization are possibly derived from various sources and/or various degrees of water-rock interaction in the subduction system.

Omphacite shows LREE enrichment and positive anomalies of $\mathrm{Sr}$ and $\mathrm{Eu}$ in a primitive mantlenormalized diagram. Metamorphic minerals, having positive anomalies of $\mathrm{Eu}$ and $\mathrm{Sr}$, can be interpreted as resulting from plagioclase recrystallization reactions. It is, however, noted that the omphacite is also characterized by a strong positive HFSE anomaly (Fig. 9). Although, general trace-element characteristics of albite are not clear, igneous plagioclase usually shows strong depletion of HFSE (Cortesogno et al. 2000). There is direct evidence that hydrothermal fluids in the serpentinized peridotite-hosted Rainbow hydrothermal system at $36^{\circ} \mathrm{N}$ on the Mid-Atlantic Ridge is characterized by LREE enrichment and positive $\mathrm{Eu}$ anomaly (Douville et al. 2002). Furthermore, LREE enrichment and positive Eu anomalies observed in fluids from the experiment involving serpentinized peridotite and are remarkably similar to patterns of REE mobility in vent fluids issuing from basalt- and serpentinized peridotite-hosted hydrothermal systems (Allen \& Seyfried 2005). Irrespective of differences in $P-T$ conditions and tectonic settings, these data are not inconsistent with the hypothesis that the studied jadeitites were formed by hydrothermal fluids related to serpentinization in subduction zones.

\section{SIGNIFICANCE OF JADEITE FOR ELEMENTAL FRACTIONATION IN SUBDUCTION ZONES}

Trace-element compositions of jadeite ( \pm omphacite) in this study indicate that jadeitites are a unique geochemical reservoir for several elements in the subduction zone. Subduction zone magmas are generally characterized by depletion of HFSE with respect to $\mathrm{REE}$ of similar incompatibility (McCulloch \& Gamble 1991; Tatsumi \& Eggins 1995; Elliott et al. 1997). The relative HFSE depletion in subduction zone magmas has been attributed to processes of mineralogical retention. For example, rutile serves an important role to retain HFSE in subduction zone eclogites (i.e. a sub-

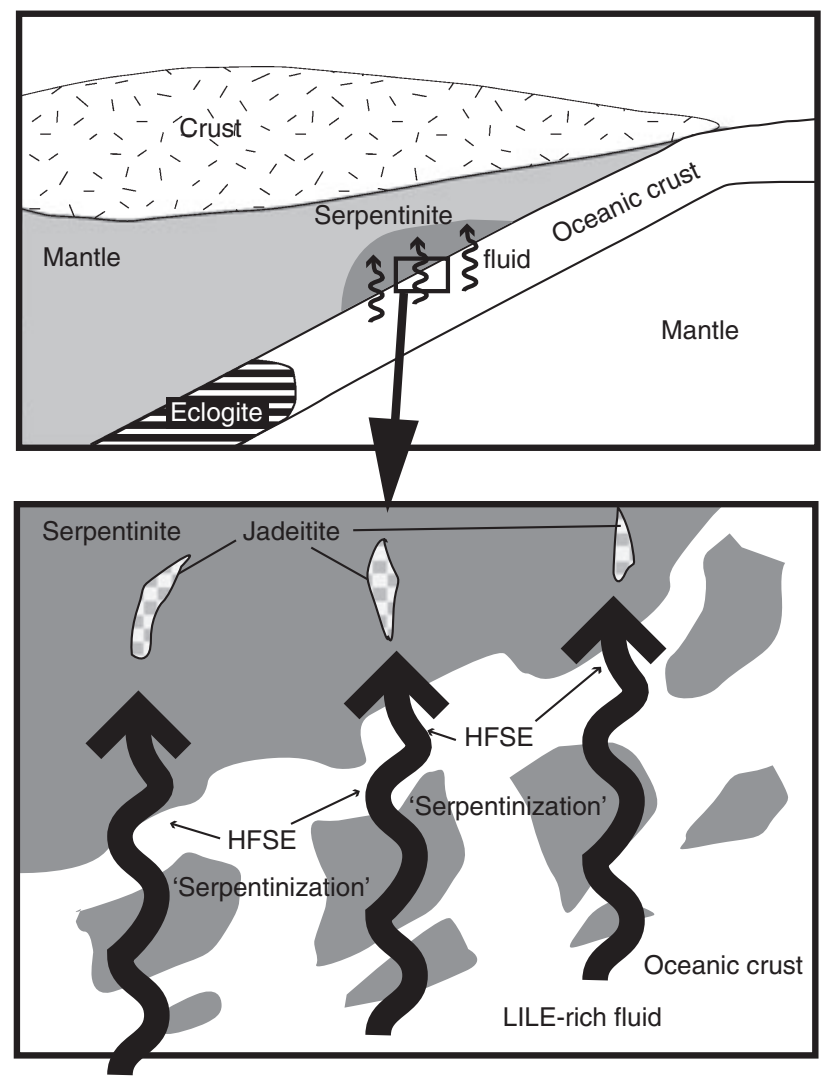

LILE-rich fluid

Fig. 11 Schematic diagram showing fluid circulation and jadeitite formation at a shallow depth in a subduction zone. Some peridotite blocks are incorporated into a subducting slab along the boundary between the mantle wedge and subducting slab. Large-ion lithophile element (LILE) enriched fluids are supplied due to dehydration of altered oceanic crust during subduction and migrate upward into the mantle wedge resulting in serpentinization of these peridotite blocks and a part of the mantle wedge mantle. A specific fluid after serpentinization continues to circulate into the subducting slab and might allow to dissolving a high field strength element (HFSE) in subducting slab. Jadeite ( \pm rutile and/or zircon) was crystallized from the fluids to form jadeitites.

ducted slab) (Rudnick et al. 2000). In this case, a HFSE-depleted metasomatizing agent is expected to be transported to the overlying mantle wedge (Brenan et al. 1995; Stalder et al. 1998; Foley et al. 2000; Rudnick et al.2000). Our results indicate that HFSE are circulated as solute in subduction zonerelated fluids, at least in specific $P-T$ conditions suitable for the formation of jadeitites. Furthermore, jadeite (+omphacite) incorporates HFSE relative to $\mathrm{REE}$. These results suggest that residual fluids after formation of jadeitites are depleted in HFSE relative to REE. Although jadeitite is an uncommon rock type on the surface of the earth, it would be widely formed in subduction zones, particularly where old (cold) slabs are subducting. We may need further discussions concerning fluidrock interactions on fractionation of HFSE relative 
to REE in subduction zones. There is now abundant evidence for a progressive release of $\mathrm{Li}$ from the subducting slab at subduction zones because $\mathrm{Li}$ is highly soluble in aqueous fluids (You et al. 1996; Moriguchi \& Nakamura 1998; Seyfried et al. 1998; Zack et al. 2003). Furthermore, large isotopic fractions in the ${ }^{7} \mathrm{Li} /{ }^{6} \mathrm{Li}$ ratio of natural samples is expected during low-temperature reactions with water (Moriguchi \& Nakamura 1998; Chan et al. 1999, 2002; Zack et al. 2003; Leeman et al. 2004; Nishio et al. 2004). Hence, Li isotopes have become a great potential tool for understanding fluid processes at subduction zones and slab input, via fluids, to the mantle wedge. Data of Li compositions of jadeitites are, however, scarce thus far.

Because jadeitites principally consist of jadeite, bulk Li contents of the studied jadeitites can be thought to be considered roughly the same as those of constituent jadeites. These values can be compared with published data on Li contents of variable rock types. The altered basalt, upper part of subducting slabs, collected from Ocean Drilling Program (ODP) Hole 504B near the Costa Rica Rift is enriched in $\mathrm{Li}$ (5.6-27.3 p.p.m.) and have heavy isotopic compositions relative to fresh midocean ridge basalt (MORB) (Chan et al. 2002) (Fig. 10). Li contents of the studied jadeitites fall into the middle to low range of those in altered MORB (Chan et al. 2002). On the other hand, studies on eclogites of high-pressure metamorphic oceanic crusts suggest a progressive loss of Li by subduction-related dehydration (Zack et al. 2003), although some eclogites still retain significant amounts of Li particularly in their clinopyroxenes (Woodland et al. 2002). Li contents of the studied jadeite overlap the middle to high range of clinopyroxene from eclogites-eclogititic rocks of highpressure metamorphic oceanic crusts (Zack et al. 2003) (Fig. 10). Jadeitites are therefore a significant sink for Li in subduction zones.

Zack et al. (2003) speculated that heavy Li is selectively released into the forearc mantle wedge in subduction zones. Simon et al. (2004) measured Li isotopic composition on Guatemalan jadeitites, characterized by high Li concentrations and reported their low $\delta 7 \mathrm{Li}$ values $(0$ to -4$)$. Decitre et al. (2002) examined behavior of Li during serpentinization of abyssal peridotites collected from the southwest Indian Ridge. They suggested that serpentine preferentially incorporates ${ }^{6} \mathrm{Li}$. It is thus obvious that Li cycling in subduction zones is still not fully understood. Further systematic Li isotope analyses of jadeitites, as well as their host serpentinites, are required to fully understand quantitative element fractionation due to fluid circulation in subduction zones.

\section{CONCLUSIONS}

This study determined trace-element compositions of jadeite ( \pm omphacite) in a lavender-colored jadeitite and green-colored omphacite-bearing jadeitite from the Itoigawa-Ohmi district of Japan, using an LA-ICP-MS technique. The origin of the jadeitites was discussed in the context of fluidassisted element circulation in subduction zones. The results are summarized below.

1. Trace-element compositions of jadeite show chemical zoning within individual grains, and show variations within each sample and between samples.

2. Primitive mantle-normalized patterns of jadeite in the samples are generally demonstrated to be high in LILE, have high LREE/HREE ratio and positive HFSE anomaly.

3. Textures and mineralogy in the studied jadeitites suggest that the jadeitites were formed as direct precipitation of minerals from aqueous fluids or complete metasomatic modification of the precursor rocks by fluids.

4. The specific fluids responsible for the formation of jadeitites are enriched in both LILE and HFSE. The fluids are related to serpentinization by slab-derived fluids in subduction zones. This process is followed by dissolving HFSE in the subducting crust as the fluids continue to circulate into the subducting crusts and serpentinized peridotites.

\section{ACKNOWLEDGEMENTS}

This study was partly supported by a Grant-in-Aid for Scientific Research of the Ministry of Education, Culture, Sports, Science and Technology of Japan to TM (No. 17740349). We wish to acknowledge the support from the 21st Century COE project (led by K. Hayakawa) and the Incubation Business Laboratory Center of Kanazawa University. We thank Tadao Nishiyama and Yasushi Mori who provided constructive comments that significantly improved the manuscript. We also thank Kazuhiro Miyazaki for his editorial efforts and valuable comments on the manuscript, and Simon Wallis and Kasey Mae Doran for some grammatical comments in the manuscript. TM is grateful to Tatsuki Tsujimori for his valuable comments on 
jadeitites during this work. Kazue Tazaki and Akihiro Tamura are thanked for EPMA and LA-ICPMS analyses, respectively. The Lavender-Jade was collected by Yuya Iwata and was kindly donated to TM.

\section{REFERENCES}

ALLEN D. E. \& SEYFRIED W. E. JR. 2005. REE controls in ultramafic hosted MOR hydrothermal system: An experimental study at elevated temperature and pressure. Geochimica et Cosmochimiaca Acta 69, 675-83.

BANNO S. 1958. Glaucophane schists and associated rocks in the Omi district, Niigata Prefecture, Japan. Japanese. Japanese Journal of Geology and Geography 29, 29-44.

BANnO S. 1998. Pumpellyite-actinolite facies of the Sanbagawa metamorphism. Journal of Metamorphic Geology 16, 117-28.

Banno S., Shibakusa H., Enami M., Wang C.-L. W. \& ERnst W. G. 2000a. Chemical fine structure of Franciscan jadeitic pyroxene from Ward Creek, Cazadero area, California. American Mineralogist 85, 1795-8.

Banno S., TORIMUmi M., OBATA M. \& NishiYama T. 2000b. Dynamics of Petrogenesis. University of Tokyo Press, Tokyo.

BARNES I. \& O'NEIL R. 1969. The relationship between fluids in some fresh alpine-type ultramafics and possible modern serpentinization, Western United States. Geological Society of American Bulletin 80, 1947-60.

Barnes I., LAmarche V. C. JR \& HimmelberG G. 1967. Geochemical evidence of present-day serpentinization. Science 156, 830-2.

Barnes I., O'Neil J. R. \& Trescases J. J. 1978. Present day serpentinization in New Caledonia, Oman and Yugoslavia. Geochimica et Cosmochimica Acta 42, 144-5.

BEARD J. S. \& Hopkinson L. 2000. A fossil, serpentinization-related hydrothermal vent, Ocean Drilling Program Leg 173, Site 1068 (Iberia Abyssal Plain): Some aspects of mineral and fluid chemistry. Journal of Geophysical Research 105, 16 527-39.

Brenan J. M., ShaW H. F., Ryerson F. J. \& Phinney D. L. 1995. Mineral-aqueous fluid partitioning of trace elements at $900^{\circ} \mathrm{C}$ and $2.0 \mathrm{GPa}$ : Constraints on the trace element chemistry of mantle and deep crustal fluids. Geochimica et Cosmochimica Acta 59, 3331-50.

Carswell D. A. \& VAN Roermund H. L. M. 2005. On multi-phase mineral inclusions associated with microdiamond formation in mantle-derived peridotite lens at Bardane on Fjørtoft, west Norway. European Journal of Mineralogy 17, 31-42.
CHAN L. H. \& Edmond J. M. 1988. Variation of lithium isotope composition in the marine environment: A preliminary report. Geochimica et Cosmochimica Acta 52, 1711-17.

Chan L. H., Edmond J. M., Thompson G. \& Gills K. 1992. Lithium isotopic composition of submarine basalts: Implications for the lithium cycle in the oceans. Earth and Planetary Science Letters 108, 151-60.

Chan L. H., Leeman W. P. \& You C.-F. 1999. Lithium isotopic composition of Central American volcanic arc lavas: Implications for modification of subarc mantle by slab-derived fluids: Correction. Chemical Geology 160, 255-80.

Chan L. H., LeEman W. P. \& You C.-F. 2002. Lithium isotopic composition of Central American volcanic arc lavas: Implications for modification of subarc mantle by slab-derived fluids: Correction. Chemical Geology 182, 293-300.

CHIHARA K. 1971. Mineralogy and paragenesis of jadeites from the Omi-Kotaki Area, Central Japan. Mineralogical Society of Japan, Special Paper 1, 147-56.

Chinara K. 1989. Tectonic significance of jadeitite in Hida Marginal Belt and Sangun Metamorphic Belt. Memirs of the Geological Society of Japan 33, 37-51 (in Japanese with English abstract).

Chinara K., Komatsu M. \& Mizota T. 1974. A joaquinite-like mineral from Ohmi, Niigata Prefecture, Central Japan. Mineralogical Journal 7, 395-9.

Chinara K., Komatsu M., Uemura T. et al. 1979. Geology and Tectonics of the Omi-Renge and Joetsu tectonic belts (5): geology and tectonics of the OmiRenge tectonic belt. Science Report of Niigata University, Series E 5, 1-61.

Coleman R. G. 1961. Jadeite deposits of the Clear Creek Area, New Idria Distric, San Benito Country, California. Journal of Petrology 2, 209-47.

Cortesogno L. L., Gaggero L. \& ZanetTi A. 2000. Rare earth and trace elements in igneous and hightemperature metamorphic minerals of oceanic gabbros (MARK area, Mid-Atlantic Ridge). Contributions to Mineralogy and Petrology 139, 373-93.

Decitre S., Deloule E., Reisberg L., James R., AGRINiER P. \& MÉvel C. 2002. Behavior of Li and its isotopes during serpentinization of oceanic peridotites. Geochemistry Geophysics Geosystems 3, 10.1029/2001GC000178.

Douville E., Charlou J. L., Oelkers E. H. et al. 2002. The rainbow vent fluids $\left(36^{\circ} 14^{\prime} \mathrm{N}, \mathrm{MAR}\right)$ : the influence of ultramafic rocks and phase separation on trace met al content in Mid-Atlantic Ridge hydrotherml fluids. Chemical Geology 184, 37-48.

Dubińska E., BYlina P., Kozlowski A. et al. 2004. $\mathrm{U}-\mathrm{Pb}$ dating of serpentinization: Hydrothermal zircon from metasomatic rodingite shell (Sudetic ophiolite, SW Poland). Chemical Geology 203, 183204. 
Elliott T., Plank T., Zindler A., White W. \& BOURDON B. 1997. Element transport from slab to volcanic front at the Mariana arc. Journal of Geophysical Research 102, 14 991-5019.

Foley S. F., BARTG M. G. \& JenNER G. 2000. Rutile/ melt partition coefficients for trace elements and an assessment of the influence of rutile on the trace element characteristics of subduction zone magmas. Geochimica et Cosmochimica Acta 64, 933-8.

Frey M., De Capitani C. \& Liou G. 1991. A new petrogenetic grid for low-grade metabasites. Journal of Metamorphic Geology 9, 497-509.

GreeN T. H. \& ADAM J. 2003. Experimentallydetermined trace element characteristics of aqueous fluid from partially dehydrated mafic oceanic crust at $3.0 \mathrm{GPa}, 650-700^{\circ} \mathrm{C}$. European Journal of Mineralogy $15,815-30$.

HARLOW G. E. 1994. Jadeitites, albitites and related rocks from the Motagua Fault Zone, Guatemala. Journal of Metamorphic Geology 12, 49-68.

HARLOW G. E. \& Sorensen S. S. 2001. Jade: Occurrence and metasomatic origin. Australian Gemmologist 21, 7-10.

HARLOW G. E. \& SORENSEN S. S. 2004. Jade (nepherine and jadeitite) and serpentinite: Metasomatic connections. In Ernst W. G. (ed.). Serpentine and Serpentinites: Mineralogy, Petrology, Geochemistry, Ecology, Geophysics, and Tectonics, pp. 76-109. Geological Society of America, Bellwether Publishing Ltd, Columbia.

Harlow G. E., Hemming S. R., Avé Lallemant H. G., Sisson V. B. \& Sorensen S. S. 2004. Two high-pressure-low-temperature sepentinite-matrix mélange belts, Motagua fault zone, Guatemala: A record of Aptian and Maastrichtian collisions. Geology 32, 17-20.

Ishida Y., Morishita T., Arai S. \& Shirasaka M. 2004. Simultaneous in-situ multi-element analysis of minerals on thin section using LA-ICP-MS. Science Reports of Kanazawa University 48, 31-42.

IwAO S. 1953. Albitite and associated jadeite rock from Kotaki District, Japan: A study in ceramic raw material. Report: Geological Survey of Japan 153, $1-26$.

JACKson S. E., Longerich H. P., DunNing G. R. \& FRYER B. J. 1992. The application of laser-ablation microprobe-inductively coupled plasma-mass spectrometry (LAM-ICP-MS) to in situ trace-element determinations in minerals. Canadian Mineralogist 30, 1049-64.

JOHNSON C. A. \& HARLOW G. E. 1999. Guatemala jadeitites and albitites were formed by deuterium-rich serpentinizing fluids deep within a subduction zone. Geology 27, 629-32.

KAWANO Y. 1939. A new occurrence of jade (jadeite) in Japan and its chemical properties. Journal of the Japanese Association of Mineralogists, Petrologists and Economic Geologists 22, 195-201 (in Japanese).
Kelley D. S., Karson J. A., Blackman D. K. et al. 2001. An off-axis hydrothermal vent field near the Mid-Atlantic Ridge at $30^{\circ} \mathrm{N}$. Nature 412, 145-9.

Komatsu M. 1990. Hida 'Gaien' Belt and Joetsu Belt. In Ichikawa K., Mizutani S., Hara I., Hada S. \& Yao A. (eds). Pre-Cretaceous Terranes of Japan, pp. 2540. Publication of ICGP Project, No. 224, Osaka.

Komatsu M., Chinara K. \& Mizota T. 1973. A new strontium-titanium hydrous silicate mineral from Ohmi, Niigata Prefecture, Central Japan. Mineralogical Journal 7, 298-301.

Kunugiza K., NaKamura E., Miyajima H., Goto A. $\&$ KOBAYASHI K. 2002. Formation of jadeite-natrolite rocks in the Itoigawa-Ohmi area of Hida marginal belt inferred from U-Pb zircon dating. Annual Meeting Abstracts of the Japanese Association of Mineralogists, Petrologists and Economic Geologists (in Japanese).

KunUGiza K., Goto A., Itaya T. \& Yokoyama K. 2004. Geological development of the Hida Gaien belt: Constraints from $\mathrm{K}-\mathrm{Ar}$ ages of high $\mathrm{P} / \mathrm{T}$ metamorphic rocks and U-Th-Pb EMP ages of granitic rocks affecting contact metamorphism of serpentinite. Journal of the Geological Society of Japan 110, 58090 (in Japanese with English abstract).

LeEman W. P., Tonarini S., Chan L. H. \& Borg L. E. 2004. Boron and lithium isotopic variations in a hot subduction zone-the southern Washington Cascades. Chemical Geology 212, 101-24.

LONGERICH H. P., JACKSON S. E. \& GÜTHER D. 1996. Laser ablation inductively coupled plasma mass spectrometric transient signal data acquisition and analyte concentration calculation. Journal of Analytical Atomic Spectrometry 11, 899-904.

MCCULLOCH M. T. \& GAMBLE J. A. 1991. Geochemical and geodynamical constraints on subduction zone magmatism. Earth and Planetary Science Letters 102, 358-74.

MCDONOUGH W. F. \& Sun S.-S. 1995. The composition of the Earth. Chemical Geology 120, 223-53.

Maekawa H., Yamamoto K., Ueno T., Osada Y. \& NoGami N. 2004. Significance of serpentinites and related rocks in the high-pressure metamorphic terranes, Circum-Pacific regions. In Ernst W. G. (ed.). Serpentine and Serpentinites: Mineralogy, Petrology, Geochemistry, Ecology, Geophysics, and Tectonics, pp. 167-85, Geological Society of America, Bellwether Publishing Ltd, Columbia.

Matsumoto K. \& Hirajima T. 2005. The coexistence of jadeite and omphacite in an eclogite-facies metaquartz diorite from the southern Sesia Zone, Western Alps, Italy. Journal of Mineralogy and Petrological Sciences 100, 70-84.

MiYajima H., Matsubara S., MiYaWaki R. \& Ito K. 1999. Itoigawaite, a new mineral, the $\mathrm{Sr}$ analogue of lawsonite, in jadeitite from the Itoigawa-Ohmi district, central Japan. Mineralogical Magazine 63, $909-16$. 
MiYaJima H., Matsubara S., MiYaWAKI R., YOKOYAMA K. \& HIROKAWA K. 2001. Rengeite $\mathrm{Sr}_{4} \mathrm{ZrTi}_{4} \mathrm{Si}_{4} \mathrm{O}_{22}$, a new mineral, the $\mathrm{Sr}-\mathrm{Zr}$ analogue of perrierite from the Itoigawa-Ohmi district, Niigata Prefecture, central Japan. Mineralogical Magazine 65, 111-20.

MiYajima H., MiYawaki R. \& Ito K. 2002. Matsubaraite $\mathrm{Sr}_{4} \mathrm{Ti}_{5}\left(\mathrm{Si}_{2} \mathrm{O}_{7}\right)_{2} \mathrm{O}_{8}$, a new mineral, the $\mathrm{Sr}-\mathrm{Ti}$ analogue of perrierite in jadeitite from the ItoigawaOhmi district, Niigata Prefecture, Japan. European Journal of Mineralogy 14, 1119-28.

MiYaJima H., Matsubara S., MiYaWaKI R. \& HiroKaWA K. 2003. Niigataite, $\mathrm{CaSrAl}_{3}\left(\mathrm{Si}_{2} \mathrm{O}_{7}\right)\left(\mathrm{SiO}_{4}\right)$ $\mathrm{O}(\mathrm{OH})$ : Sr-analogue of clinozoisite, a new member of the epidote group from the Itoigawa-Ohmi district, Niigata Prefecture, central Japan. Journal of Mineralogical and Petrological Sciences 98, 118-29.

MiYAZAKI K. \& OKAMURA K. 2002. Thermal modelling in shallow subduction: An application to low $\mathrm{P} / \mathrm{T}$ metemorphism of the Cretaceous Shimanto Accretionary Complex, Japan. Journal of Metamorphic Geology 20, 441-52.

MoriguChi T. \& NAKamuRa E. 1998. Across-are variation of $\mathrm{Li}$ isotopes in lavas and implications for crust/mantle recycling at subduction zones. Earth and Planetary Science Letters 163, 167-74.

MORISHITA T. 2005. Occurrence and chemical composition of barian feldspars in a jadeitite from the Itoigawa-Ohmi district in the Renge high-P/T-type metamorphic belt, Japan. Mineralogical Magazine 69, 39-51.

Morishita T., ISHIDA Y. \& ARAI S. 2005a. Simultaneous determination of multiple trace element compositions in thin $(<30 \mu \mathrm{m})$ layers of BCR-2G by 193 $\mathrm{nm}$ ArF excimer laser ablation-ICP-MS: Implications for matrix effect and element fractionation on quantitative analysis. Geochemical Journal 39, 32740.

Morishita T., Ishida Y., Arai S. \& Shirasaka M. 2005b. Determination of multiple trace element compositions in thin $(<30 \mu \mathrm{m})$ layers of NIST SRM 614 and 616 using laser ablation ICP-MS. Geostandards and Geoanalytical Research 29, 107-22.

NAKamizU M., OKaDA M., YamaZaKi T. \& KomatsU M. 1989. Metamorphic rocks in the Omi-Renge serpentinite mélange, Hida Marginal Tectonic Belt, Central Japan. Memoirs of the Geological Society of Japan 33, 21-35 (in Japanese with English abstract).

NISHIMURA Y. 1998. Geotectonic subdivision and areal extent of the Sangun belt, Inner Zone of Southwest Japan. Journal of Metamorphic Geology 16, 129-40.

Nishio Y., Nakai S., Yamamoto J., Sumino H., Matsumoto T., Prikhod'Ko V. S. \& ARAi S. 2004. Lithium isotopic systematic of the mantle-derived ultramfic xenoliths: Implications for EM1 origin. Earth and Planetary Science Letters 217, 245-61.

Oba T., Nakagawa Y., Kanayama K. \& Watanabe T. 1992. Notes on rock-forming minerals in the Joetsu district, Niigata Prefecture, Japan. (5) lavender jadeite from the Kotaki river. Bulletin of Joetsu University of Education 11, 367-75.

OHMORI K. 1939. Optical properties of jade (jadeite) in Japan. Journal of the Japanese Association of Mineralogists, Petrologists and Economic Geology 22, 201-12 (in Japanese).

OKAY A. I. 1997. Jadeite-K-feldspar rocks and jadeitites from northwest Turkey. Mineralogical Magazine 61, 835-44.

Pearce N. J. G., Perkins W. T., Westgate J. A. et al. 1997. A compilation of new and published major and trace element data for NIST SRM 610 and NIST SRM 612 glass reference materials. Geostandards Newsletter: The Journal of Geostandards and Geoanalysis 21, 114-44.

Rubatto D., Gebauer D. \& Fanning M. 1998. Jurassic formation and Eocene subduction of the ZermattSaas-Fee ophiolites: Implications for the geodynamic evolution of the Central and Western Alps. Contributions to Mineralogy and Petrology 132, 269-87.

Rubatto D., Gebauer D. \& Compagnoni R. 1999. Dating of eclogite-facies zircons: The age of Alpine metamorphism in the Sesia-Lanzo Zone (Western Alps). Earth and Planetary Science Letters 167, 141-58.

RUdNiCK R. L., BARTH M., HORN I. \& MCDONOUGH W. F. 2000. Rutile-bearing refractory eclogites: Missing link between continents and depleted mantle. Science 287, 278-81.

SAKAI M. \& AKAI J. 1994. Strontium, barium and titanium-bearing minerals and their host rocks from Ohmi, Japan. Scientific Reports of Niigata University, Series E (Geology and Mineralogy) 9, $97-118$.

Seitz H.-M., Brey G. P., Stachel T. \& Harris J. 2003. Li abundances in inclusions in diamonds from the upper and lower mantle. Chemical Geology 201, $307-18$.

Seyfried E. W. JR, Chen X. \& Chan L.-H. 1998. Trace element mobility and lithium isotope exchange during hydrothermal alteration of seafloor weathered basalt: An experimental study at $350^{\circ} \mathrm{C}, 500$ bars. Geochimica et Cosmochimica Acta 62, 949-60.

Shi G. H., Cui W. Y., Tropper P., Wang C. Q., Shu G. M. \& YU H. 2003. The petrology of a complex sodic and sodic-calcic amphibole association and its implications for the metasomatic processes in the jadeitite area in northwestern Myanmar, formerly Burma. Contributions to Mineralogy and Petrology 145, 355-76.

Shi G. H., StöckherT B. \& CUI W. Y. 2005a. Kosmochlor and chromian jadeite aggregate from the Myanmar jadeitite area. Mineralogical Magazine 69, 1059-75.

Shi G. H., Tropper P., Cui W., Tan J. \& Wang C. 2005b. Methane $\left(\mathrm{CH}_{4}\right)$-bearing fluid inclusions in the Myanmar jadeitite. Geochemial Journal 39, 503-16. 
Shibata K. \& NozaWA T. 1968. K-Ar age of Omi schist, Hida Mountain, Japan. Bulletin of the Geological Survey of Japan 19, 243-6.

Shigeno M., Mori Y. \& NishiYama T. 2005. Reaction microtextures in jadeitites from the Nishisonogi metamorphic rocks, Kyusyu, Japan. Journal of Mineralogical and Petrological Sciences 100, 237-46.

Simons K. K., LANGMUir C. H. \& HARLOW G. E. 2004. Lithium isotopic composition of Guatemalan jadeitites. EOS Trans. AGU abstract 85 (47), Fall Meeting.

Sorensen S. S., Harlow G. E. \& Rumble D. III. 2003. SIMS oxygen isotope analyses of jadeitite: Trace element correlations, fluid compositions, and temperature estimates. Geological Society of America Abstract with Program 35, no. 6 (abstract \#225; CDROM, 90-7).

SPEAR F. S. 1993. Metamorphic Phase Equilibria and Pressure-Temperature-Time Paths. Monograph 1. Mineralogical Society of America, Washington, DC, USA. 799 pp.

Stalder R., Foley S. F., Brey G. P. \& Horn I. 1998. Mineral-aqueous fluid partitioning of trace elements at $900-1200^{\circ} \mathrm{C}$ and $3.0-5.7 \mathrm{GPa}$ : New experimental data for garnet, clinopyroxene, and rutile, and implications for mantle metasomatism. Geochimica et Cosmochimica Acta 62, 1781-801.

TATSumi Y. \& EGGINS S. 1995. Subduction Zone Magmatism. Blackwell, Oxford.

TomascaK P. B., Widom E., Benton L. D., Goldstein S. L. \& RYAN J. G. 2002. The control of lithium budgets in island arcs. Earth and Planetary Science Letters 196, 227-38.

Tsujimori T. 2002. Prograde and retrograde P-T paths of the Late Paleozoic glaucophane eclogite from the Renge metamorphic belt, Hida Moundains, Southwestern Japan. International Geological Review 44, 797-818.

TsuJIMORI T. 2004. Origin of serpentinites in the Omi serpentinite melange (Hida Mountains, Japan) deduced from zoned Cr-spinel. Journal of the Geological Soceity of Japan 110, 591-7 (in Japanese with English abstract).

TSUJIMORI T. \& ITAYA T. 1999. Blueschist-facies metamorphism during Paleozoic orogeny in southwest- ern Japan: Phengite K-Ar ages of blueschist-facies tectonic blocks in a serpentinite melange beneath early Paleozoic Oeyama ophiolite. Island Arc 8, 190-205.

TSUJIMORI T., IsHiwatari A. \& BANNO S. 2000. Eclogitic glaucophane schist from the Yunotani valley in Omi Town, the Renge metamorphic belt, the Inner Zone of southwestern Japan. Journal of the Geological Society of Japan 106, 353-62 (in Japanese with English abstract).

Tsukada K., TAKeuchi M. \& KoJima S. 2004. Redefinition of the Hida Gaien belt. Journal of Geological Society Japan 110, 640-58.

VAN BAALEN M. R. 1993. Titanium mobility in metamorphic systems: A review. Chemical Geology 110, 233-49.

VARD E. \& WiLliams-Jones A. E. 1993. A fluid inclusion study of vug minerals in dawsonite-altered phonolite sills, Montreal, Quebec: Implications for HFSE mobility. Contributions to Mineralogy and Petrology 113, 410-23.

Woodland A. B., Seitz H.-M., Altherr R., MarSCHALL H., OLKER B. \& LUDWIG T. 2002. Li abundances in eclogite minerals: A clue to a crustal or mantle origin? Contributions to Mineralogy and Petrology 143, 587-601.

YAMANE M., BAMBA M. \& BAMBA T. 1988. The first finding of orbicular chromite ore in Japan. Mining Geology 38, 501-8.

YoKOYAMA K. 1985. Ultramafic Rocks in the Hida marginal zone. Memoirs of the National Science Museum, Tokyo 18, 5-18.

YokoYama K. \& SAMeshima T. 1982. Miscibility gab between jadeite and omphacite. Mineralogical Journal 11, 53-61.

You C.-F., Castillo P. R., Geiskes J. M., Chan L. H. \& SPIVACK A. J. 1996. Trace element behavior in hydrothermal experiments: Implications for fluid processes at shallow depths in subduction zones. Earth and Planetary Science Letters 140, 41-52.

Zack T., TOMascak P. B., RUdNick R. L., DALPÉ C. \& MCDONOUGH W. F. 2003. Extremely light Li in orogenic eclogites: The role of isotope fractionation during dehydration in subducted oceanic crust. Earth and Planetary Science Letters 208, 279-90. 